\title{
Strategies for the control of Rhipicephalus microplus ticks in a world of conventional acaricide and macrocyclic lactone resistance
}

\author{
Roger I. Rodriguez-Vivas ${ }^{1}$ (D) $\cdot$ Nicholas N. Jonsson ${ }^{2} \cdot$ Chandra Bhushan $^{3}$
}

Received: 7 August 2017 / Accepted: 6 November 2017 / Published online: 20 November 2017

(C) The Author(s) 2017. This article is an open access publication

\begin{abstract}
Infestations with the cattle tick, Rhipicephalus microplus, constitute the most important ectoparasite problem for cattle production in tropical and subtropical regions worldwide, resulting in major economic losses. The control of $R$. microplus is mostly based on the use of conventional acaricides and macrocyclic lactones. However, the intensive use of such compounds has resulted in tick populations that exhibit resistance to all major acaricide chemical classes. Consequently, there is a need for the development of alternative approaches, possibly including the use of animal husbandry practices, synergized pesticides, rotation of acaricides, pesticide mixture formulations, manual removal of ticks, selection for host resistance, nutritional management, release of sterile male hybrids, environmental management, plant species that are unfavourable to ticks, pasture management, plant extracts, essential oils and vaccination. Integrated tick management consists of the systematic combination of at least two control technologies aiming to reduce selection pressure in favour of acaricide-resistant individuals, while maintaining adequate levels of animal production. The purpose of this paper is to present a current review on conventional acaricide and macrocyclic lactone resistance for better understanding
\end{abstract}

Roger I. Rodriguez-Vivas

rvivas@correo.uady.mx

1 Facultad de Medicina Veterinaria y Zootecnia, Campus de Ciencias Biológicas y Agropecuarias, Universidad Autónoma de Yucatán, km. 15.5 Carretera Mérida-Xmatkuil, 97000 Mérida, Yucatán, Mexico

2 College of Medical, Veterinary and Life Sciences, University of Glasgow, G61 1QH, Glasgow, UK

3 Bayer Animal Health GmbH, Kaiser-Wilhelm-Alee 10, 51368 Leverkusen, Germany and control of resistant ticks with particular emphasis on R. microplus on cattle.

Keywords Rhipicephalus microplus · Acaricides · Macrocyclic lactone $\cdot$ Resistance $\cdot$ Integrated tick management

\section{Introduction}

Ticks are economically the most important pests of cattle and other domestic species worldwide (Jongejan and Uilenberg 1994). The FAO (1987) reported that more than $80 \%$ of the world's cattle population is infested with ticks. The cattle tick Rhipicephalus microplus (formerly Boophilus microplus) is one of the most important livestock pests in tropical and subtropical areas of the world. Economic losses due to $R$. microplus are related to depression of milk production and liveweight gain, mortality, hide damage, morbidity, the cost of control and the effects of tick-transmitted haemoparasites (Babesia bigemina, Babesia bovis and Anaplasma marginale). Recently, in Brazil and Mexico, annual losses from tick infestation of $R$. microplus were estimated to be US\$3.24 billion (Grisi et al. 2014) and US\$573.61 million per annum (Rodriguez-Vivas et al. 2017), respectively.

Acaricides and macrocyclic lactones (MLs) have played an important role in the control of ticks. However, populations of several tick species mainly in tropical and subtropical countries have developed resistance to all major classes of these compounds due to the high intensity of their use in tick management (Rodriguez-Vivas et al. 2006a, b; Perez-Cogollo et al. 2010a). This has driven to the development of new chemical and non-chemical approaches to control. Integrated pest management involves the systematic application of two or more technologies to control tick populations which adversely affect the host species. The ultimate aim is to achieve 
parasite control in a more sustainable, environmentally compatible and cost-effective manner than is achievable with a single, stand-alone technology (Willadsen 2006). The purpose of this paper is to present an updated review on conventional acaricide and macrocyclic lactone resistance for better understanding and control of resistant tick species with particular emphasis on R. microplus on cattle.

\section{Chemical control of Rhipicephalus microplus}

The chemicals used in the treatment of ectoparasites of veterinary importance act either systemically, following uptake of the compound from host tissues, or by direct contact with the target parasites following external application (RodriguezVivas et al. 2014a). With the exception of acarine/insect growth regulators, virtually all ectoparasiticides are neurotoxins, exerting their effect on the ectoparasite nervous system (Taylor 2001). Traditional methods for the delivery of an acaricide treatment to cattle to control ticks required formulations such as a wettable powder, emulsifiable concentrate or flowable products. Currently used conventional acaricides and MLs can be applied to cattle by immersion of animals in a dipping vat, by hand-operated spray, in a spray race, by injection, as a pour-on, in an intraruminal bolus, as an ear tag, or using other pheromone-acaricide-impregnated devices (George et al. 2004). The major classes and general characteristics of conventional acaricides and MLs to control ticks on cattle are listed in Table 1.

Acaricide mixtures and synergized formulations have been also used to control ticks on cattle, although there is considerable variation among countries regarding the licensing and registration of mixtures. Simple modelling shows that the use of a hypothetical drug mixture, which might also have broader spectrum of activity, and against which there is no pre-existing detectable resistance, should extend the life of a formulation (McKenzie 1996). This theoretical argument does not carry much weight in practice; however, because in the present day, products are rarely formulated as mixtures until they have been on the market for some time. Consequently, the actual frequencies of resistance-conferring alleles are many orders of magnitude higher than those expected against a novel product and the actual benefit is unlikely to be perceptible. There is variation among countries in the extent to which regulatory standards allow for the registration of acaricide mixtures. Some of the mixtures that are commercially available include compounds with synergistic activity. Several organophosphates (OPs) synergize the toxicity to R. microplus of deltamethrin and cypermethrin. In Australia, a combination product containing deltamethrin, chlorfenvinphos, cypermethrin and ethion has been used to control $R$. microplus (George et al. 2004). In the USA, Davey et al. (2013) evaluated the efficacy of a mixture of OP acaricides (dichlorvos and tetrachlorvinphos) as a spray at 0.3 and $0.15 \%$ active ingredient on cattle infested with immature and mature parasitic stages of OP-resistant $R$. microplus. The overall percentage mortality provided by 0.3 and $0.15 \%$ of the active ingredient was 87.6 and $85.3 \%$, respectively. Although this OP mixture provided useful control against a highly OPresistant strain of ticks, the control fell short of the 99\% level required for use in the US Cattle Fever Tick Eradication Program. In Brazil, the most common mixtures of synthetic

Table 1 The major classes and general characteristics of conventional acaricides and MLs to control ticks on cattle worldwide

\begin{tabular}{|c|c|c|}
\hline Drug classes & Active compounds & Characteristics \\
\hline Organochlorines & $\begin{array}{l}\text { (a) Chlorinated ethane derivatives: DDT, DDE } \\
\text { (dichloro-diphenyldichloro-ethane) and DDD } \\
\text { (dicofol, methoxychlor) } \\
\text { (b) Cyclodienes, chlordane, aldrin, dieldrin, } \\
\text { hepatochlor, endrin, toxaphene } \\
\text { (c) Hexachlorocyclohexanes (HCH): benzene } \\
\text { hexachloride (BHC) which includes the } \\
\gamma \text {-isomer, lindane }\end{array}$ & $\begin{array}{l}\text { A broad spectrum of activity on arthropods but are not } \\
\text { free from toxicity; they are highly persistent in the } \\
\text { environment, in milk and in meat, and may be retained } \\
\text { in the fat of vertebrates (Beugnet and Franc 2012). }\end{array}$ \\
\hline Synthetic pyrethroids & $\begin{array}{l}\text { Type I. Lack an } \alpha \text {-cyano group which is present at } \\
\text { the phenylbenzyl alcohol position of type II } \\
\text { pyrethroids (Soderlund et al. 2002). The main } \\
\text { pyrethroid acaricides currently in use are the } \\
\alpha \text {-cyano-substituted pyrethroids such as } \\
\text { cypermethrin, deltamethrin, cyhalothrin and } \\
\text { flumethrin (George et al. 2004) }\end{array}$ & $\begin{array}{l}\text { The spectrum of activity varies upon the molecules. } \\
\text { Permethrin and deltamethrin are both insecticides and } \\
\text { acaricides, whereas flumethrin is mainly an acaricide. } \\
\text { Cypermethrin, deltamethrin and cyhalothrin are } \\
\text { examples of SPs that are effective on susceptible ticks } \\
\text { (>98\% efficacy) (Rodriguez-Vivas et al. (2014a). } \\
\text { Flumethrin was designed for application to cattle as } \\
\text { pour-on, but there is also an emulsifiable concentrate } \\
\text { formulation that can be applied as a dip or spray. The } \\
\text { active ingredient in the pour-on has a remarkable ca- } \\
\text { pacity for spreading rapidly on the skin and hair from } \\
\text { points of application along the dorsal line of an animal } \\
\text { to all areas of the body (George et al. 2004). }\end{array}$ \\
\hline
\end{tabular}


Table 1 (continued)

\begin{tabular}{ll}
\hline Drug classes & Active compounds \\
\hline Organophospates & $\begin{array}{l}\text { Ethion, chlorpyrifos, chlorfenvinphos and } \\
\text { coumaphos are four of the most widely used } \\
\text { OPs for treatment of tick-infested cattle (Abbas } \\
\text { et al. 2014). }\end{array}$ \\
Amidines & $\begin{array}{l}\text { Among the formamidines, only amitraz is } \\
\text { currently used for the control of cattle ticks } \\
\text { (Jonsson and Hope 2007). }\end{array}$
\end{tabular}

Characteristics

Can be extremely toxic in mammals. They are generally active against fly larvae, flies, lice, ticks and mites on domestic livestock and fleas and ticks on dogs and cats, although activity varies between compounds and differing formulations (MacDonald 1995).

Amitraz is toxic against mites, lice and ticks in domestic livestock. It has been widely used on cattle in dips, sprays or pour-on formulations for the control of single-host and multi-host tick species (Taylor 2001). Amitraz continues to be one of the most popular acaricides for the control of $R$. microplus in Australia, southern Africa and Latin America (Jonsson and Hope 2007). Amitraz applied by aspersion to cattle infested with $R$. microplus had a therapeutic efficacy of 99.5-100\% in the Mexican tropics (Aguilar-Tipacamu and Rodriguez-Vivas 2003).

Phenylpyrazoles

Insect growth regulators (IGRs)

Macrocyclic lactones
Fipronil is used worldwide for the treatment and control of flea and tick infestations on cattle, cats and dogs (Taylor 2001; George et al. 2004).

Based on their mode of action they are divided into (a) chitin synthesis inhibitors (benzoylphenyl ureas), (b) chitin inhibitors (triazine/pyrimidine derivatives) and (c) juvenile hormone analogues (Taylor 2001).

Avermectin: doramectin, selamectin, abamectin, ivermectin and eprinomectin

Milbemycins: Moxidectin, milbemycin oxime Spinosyns: spinosad
Fipronil applied as a pour-on to cattle infested with R. microplus had a therapeutic efficacy greater than 99\% (Davey and George 1998).

IGRs constitute a group of chemical compounds that do not kill the target parasite directly, but interfere with the growth and development. They act mainly on immature stages of the parasites and as such are not usually suitable for the rapid control of established adult populations of parasites. Fluazuron is efficacious against ticks and some mite species. The adverse consequences for ticks on cattle treated with a pour-on of this acaricide are the reduction of the fecundity and fertility of engorged females to near zero, and mortality of immature ticks because they unable to moult to the next instar (George et al. 2004).

MLs are broad-spectrum antiparasitic drugs widely used to control endoparasites and ectoparasites. The efficacy of ivermectin, doramectin and moxidectin for the control of $R$. microplus populations resistant to OPs, amidine and SPs has been demonstrated (Sibson 1994; Aguilar-Tipacamu and Rodriguez-Vivas 2003). In Mexico, moxidectin (1\%) has been shown to have an efficacy against natural infestation of $R$. microplus greater than $95 \%, 28$ days after application (Aguilar-Tipacamu and Rodriguez-Vivas 2003). Arieta-Román et al. (2010) showed that the long-acting moxidectin-10\% $(1 \mathrm{mg} / \mathrm{kg})$ and ivermectin-3.15\% (0.63 mg/kg) have an efficacy against natural infection of $R$. microplus greater than $95 \%, 70$ and 56 days after applications, respectively. Eprinomectin is used against endo-ectoparasites without withdrawal time in milk and meat after its pour-on administration at $0.5 \mathrm{mg} / \mathrm{kg}$ (Davey and George 2002). In the USA, Davey et al. (2001) reported that spinosad applied topically to cattle using spray formulations proved effective to control cattle tick infestations. pyrethroids (SPs) and OPs are formulations of cypermethrin and chlorpyriphos, with or without a synergist (i.e. pyperonylbutoxide (PBO)). In Brazil, a pour-on formulation of fluazuron + abamectin is available in the market (SINDAN
2013). In Mexico, mixtures of acaricides are available in the market and flumethrin + cyfluthrin, chlorpyriphos + permethrin and cypermethrin + cymiazole are the most used (Rodriguez-Vivas et al. 2006a). 


\section{Acaricide resistance in Rhipicephalus microplus}

\section{Definition of resistance}

The definition of resistance has changed with time and remains the subject of discussion. In 1957, the WHO defined resistance as "the development of an ability to tolerate toxicants which would prove lethal to the majority of individuals in a normal population of the same species". Later, in 1992, the WHO defined resistance in arthropods as "an inherited characteristic that imparts an increased tolerance to a pesticide, or group of pesticides, such that the resistant individuals survive a concentration of the compound(s) that would normally be lethal to the species". In this paper, our definition of acaricide resistance is a specific heritable trait(s) in a population of ticks, selected as a result of the population's contact with an acaricide, which results in a significant increase in the percentage of the population that survives after exposure to a given concentration of that acaricide. In a dose-response bioassay, it is considered that there is acaricide resistance when the $95 \%$ confidence limit of the $50 \%$ lethal dose of a tested population does not overlap that of a susceptible reference strain (Robertson et al. 2007). Nonetheless, reference will be made to other definitions (Rodriguez-Vivas et al. 2012a).

\section{Phenotypic and genotypic resistance}

A distinction is made between the resistance phenotype and the resistance genotype. The resistance phenotype could be considered as how resistant or susceptible a tick is to the effects of an application of any given acaricide. The resistance genotype is the genetic composition of the tick, which leads to the expression of the resistance phenotype. It is important to note that the same resistance phenotype can be conferred by different genetic variants (Guerrero et al. 2014).

\section{Phenotypic resistance}

In bioassays, the evaluation of dose responses (mortalities) remains the most definitive method of quantifying acaricide resistance in a population of ticks drawn from the field and in which the frequencies of all possible resistance-conferring alleles are unknown. For routine diagnostics, molecular testing for specific mutations can only identify known mechanisms. Although each individual tick can be susceptible or resistant to a given dose of an acaricide, the resistance phenotype is usually quantified and expressed in terms of the phenotype of a tick population. There are two related ways of expressing this: (1) the proportion of ticks that are not killed by a given acaricide concentration (discriminating dose or DD) and (2) the ratio of the dose of acaricide required to kill a given proportion of a test population (i.e. 50,90 or $99 \%$ ) in comparison with a susceptible reference strain (Rodriguez-Vivas et al. 2012a; Guerrero et al. 2014).

In bioassays, there are four ranges of acaricide concentrations: (a) no mortality of any genotype (no selection), (b) mortality of SS and RS (resistance recessive), (c) mortality of SS only (resistance dominant) and (d) all genotypes killed (no selection) (Fig. 1).

The FAO (2004) recommended some specific bioassay techniques to test resistance to acaricides in ticks. The larval packet test (LPT) developed by Stone and Haydock (1962) has been used extensively for the diagnosis of resistance in field studies and also for the characterization of resistance mechanisms to SP and OP and in ticks. It is considered to be a highly repeatable bioassay technique (Jonsson et al. 2007), although it is limited by the labour and time required to obtain results (Guerrero et al. 2014). The larval immersion test (LIT) was developed by Shaw (1966) and is mainly used to characterize resistance mechanisms to macrocyclic lactones and amitraz (Rodriguez-Vivas et al. 2006a; PerezCogollo et al. 2010a). Recent modified LIT techniques using syringes have been developed to reduce the labour required for the traditional Shaw test (Sindhu et al. 2012). The use of microtiter plates has proven advantageous in automated highthroughput screening (White et al. 2004). Lovis et al. (2013) developed the larval tarsal test (LTT), a sensitive, efficient bioassay to enable high throughput of many compounds. The LTT produced resistance factors comparable to those obtained with the LPT. In the field, the adult immersion test (AIT) (FAO 2004) is probably the most widely used bioassay technique, although it has been shown to be a poor test (Jonsson et al. 2007). The AIT uses engorged female ticks which are immersed in technical or commercial acaricides (Guerrero et al. 2014).

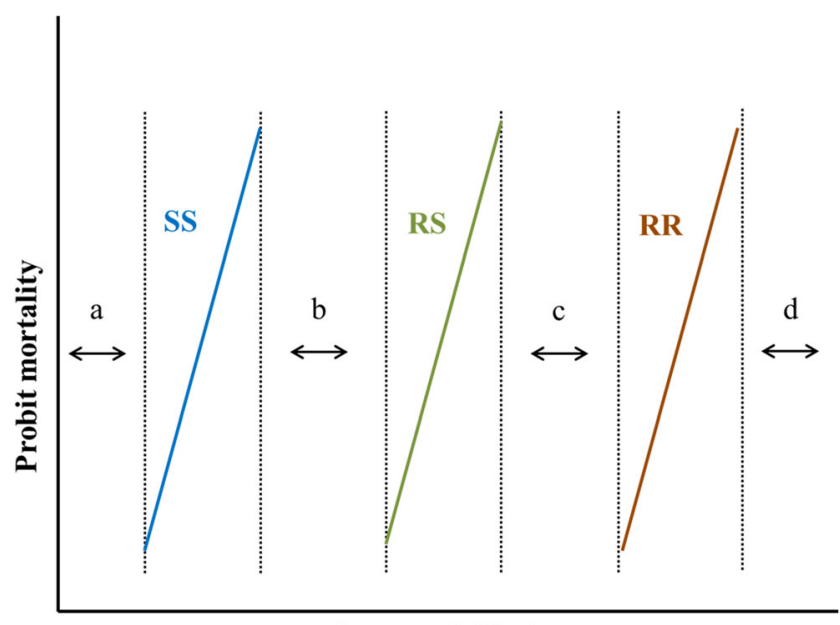

Log acaricide dose

Fig. 1 Four ranges of acaricide concentrations. a No mortality of any genotype (no selection). b Mortality of SS only (resistance dominant). c Mortality of RS and SS (resistance recessive). d All genotype killed (no selection) 
The discriminating dose (DD) test uses any bioassay technique in which a single concentration, usually at double the $\mathrm{LC}_{99.9}$ or $\mathrm{LC}_{99}$ of a known susceptible strain is used to discriminate between susceptible and resistant tick populations (FAO 2004). The sample is either described as resistant or susceptible according to an arbitrary cut value, or as the percentage of larvae that survived the treatment (although this should not be taken to extend to the expected efficacy of the acaricide in the field). One major problem with this approach is the wide confidence intervals seen at $\mathrm{LC}_{99.9}$ for most bioassays. Hence, it is difficult (or impossible) to accurately determine a value for $\mathrm{LC}_{99}$ or $\mathrm{LC}_{99.9}$ with any confidence (Jonsson et al. 2007).

A full dose-response bioassay, in which replicates of ticks are exposed to serial dilutions of acaricide, is required to properly quantify the phenotypic resistance of $R$. microplus populations to acaricides and is an obvious prerequisite for the application of a discriminating dose method. Probit analysis is then used to determine the lethal concentration (LC) required to kill 50,90 or $99 \%$ of the population $\left(\mathrm{LC}_{50}, \mathrm{LC}_{90}\right.$ or $\left.\mathrm{LC}_{99}\right)$ (Robertson et al. 2007). The resistance ratio or resistance factor ( $R R$ or RF) is the "LC value of the tested sample divided by the LC value of a reference strain" (FAO 1987). Usually, the $\mathrm{LC}_{50}$ value is used for this purpose because it can be most accurately determined. The use of other $\mathrm{LCs}$ (i.e. $\mathrm{LC}_{90}, \mathrm{LC}_{95}$ or $\mathrm{LC}_{99}$ ) (Miller et al. 2007a; Cabrera-Jimenez et al. 2008; RodriguezVivas et al. 2012b) and the slope (i.e. population response to increasing doses of the acaricide) (Robertson et al. 2007) are required to fully characterize the resistance.

Various arbitrary criteria have been proposed to evaluate the resistance level of $R$. microplus to acaricides. Beugnet and Chardonnet (1995) considered tick populations to be susceptible to $\mathrm{SP}$ when $\mathrm{RF}$ values (measured at the $\mathrm{LC}_{50}$ ) were $<3.0$, tolerant $3-5$ and resistant $\geq 5$.0. For SP, Rodriguez-Vivas et al. (2012b) recommended using RFs for both $\mathrm{LCs}\left(\mathrm{LC}_{50}+\mathrm{LC}_{99}\right)$. They considered populations to be susceptible when both $\mathrm{RF}$ values (judged by $\mathrm{LC}_{50}$ and $\mathrm{LC}_{99}$ ) were $<3.0$ and resistant when $R F$ values were $>5.0$. Populations were considered tolerant when one or both RF values were 3-5. Castro-Janer et al. (2011) suggested using the following criteria for ivermectin resistance: susceptible $R_{50} \leq 1$, low resistance $R_{50}>1 \leq 2$ and resistant $\mathrm{RF}_{50}>2$. Resistance ratios for SPs are high compared with compared with OP, amitraz and MLs, and substantial inter-population variation in the phenotypic level of acaricide resistance has been reported worldwide (Table 2).

\section{Genotypic resistance}

Increasingly, it is possible to describe the genotypic resistance profile of a tick or a population of ticks as molecular markers for resistance status become available. The first markers of resistance were developed for SPs. He et al. (1999) studied the molecular mechanism of resistance to SPs in R. microplus and obtained and sequenced a partial para-homologous sodium channel cDNA from susceptible and SP-resistant strains. A point mutation (T2134A) that results in an amino acid change $(\mathrm{F} \rightarrow \mathrm{I})$ was identified in a highly conserved domain III segment 6 of the homologous sodium channel gene from ticks that were resistant to SPs (He et al. 1999). This was followed by the discovery of two new SNPs in domain II segments 4 and 5 (C190A) of the linker region of the sodium channel gene in R. microplus (Morgan et al. 2009; Jonsson et al. 2010a). Stone et al. (2014) studied R. microplus populations from the USA and Mexico and found resistanceconferring SNPs in domains II and III of the para-sodium channel gene associated with SP resistance. Additionally, the authors discovered a putative super-kdr SNP in domain II (T170C). Recently, van Wyk et al. (2016) found that the C190A mutation within domain II of the sodium channel is the main pyrethroid resistance mechanism for $R$. microplus in South African tick populations.

Molecular genetic markers for OP resistance have been slower to emerge, reflecting a higher degree of complexity of the OP-target-detoxification system. Point mutations in the gene encoding acetylcholinesterase (AChE) that result in production of an altered enzyme have been shown to be a major mechanism of OP resistance in several insects (Temeyer et al. 2007). Baxter and Barker (1998) isolated the first putative AChE gene (AChE1) in R. microplus larvae from Australia. This was the first report of alternative splicing in an AChE gene from $R$. microplus. Two other putative $R$. microplus $\mathrm{AChE}$ genes (AChE2 and AChE3) have since been discovered (Hernandez et al. 1999; Temeyer et al. 2004). Temeyer et al. (2010) expressed three acetylcholinesterase-like transcripts isolated from two OP-resistant and one OP-susceptible strain of $R$. microplus and showed that variant alleles existed among individuals in a strain that showed differential response to OP. The availability of the cDNA sequences for susceptible or OPinsensitive AChEs allowed rapid identification of OP resistance mutations in AChEs responsible for OP insensitivity and development of rapid molecular assays to determine the presence of specific OP-resistant mutations. Four (HQ184947, HQ184946, HQ184944, HQ184943) novel amino acid substitutions were identified in the AChE2 gene of resistant field isolates collected from the state of Bihar, India (Ghosh et al. 2015). Recently, Singh et al. (2016) reported six point mutations in the gene AChE3 in strains of $R$. microplus from India (I48L, I54V, R86Q, V71A, I77M and S79P), in which the first three were previously associated to resistance against OPs in the Mexican San Roman strain (Temeyer et al. 2007) and the other three were reported for the first time. Nagar et al. (2016) studied the role of mutations in esterase genes (carboxylesterase and $\mathrm{AChE2}$ ) in the development of OP resistance in R. microplus ticks from India. Four amino acid substitutions (viz. V297I, S364T, H412Y and R468K) were found in AChE2 gene of resistant field isolates and in reference resistant lines. 
Table 2 Phenotypic level of acaricide resistance (resistance factor) in R. microplus reported worldwide

\begin{tabular}{|c|c|c|c|c|c|}
\hline Ixodicides or MLs & $\mathrm{RF}_{50}$ & $\mathrm{RF}_{90}$ & $\mathrm{RF}_{99}$ & Author & Country \\
\hline \multicolumn{6}{|l|}{ Phenylpyrazoles } \\
\hline \multirow[t]{3}{*}{ Fipronil } & 4.6 & - & 8.5 & Miller et al. (2013) & USA \\
\hline & $0.7-1.5$ & $0.8-2.0$ & - & Lovis et al. (2013) & Argentina \\
\hline & 1.8 & - & 0.9 & Rodriguez-Vivas et al. (2013) & Mexico \\
\hline Pyriprol & $0.7-2.5$ & $0.5-1.9$ & - & Lovis et al. (2013) & Argentina \\
\hline \multicolumn{6}{|l|}{ Pyrethroids } \\
\hline \multirow[t]{4}{*}{ Cypermethrin } & $0.3-2599$ & - & $0.7-5000$ & Rodriguez-Vivas et al. (2012b) & Mexico \\
\hline & $>246$ & - & $>72.2$ & Rodriguez-Vivas et al. (2013) & Mexico \\
\hline & $1.7-57.0$ & $2.1-116.2$ & - & Lovis et al. (2013) & Argentina \\
\hline & $8.7-33.9$ & $38.3-48.8$ & - & Lovis et al. (2013) & Australia \\
\hline \multirow[t]{2}{*}{ Flumethrin } & $0.9-23.0$ & $0.2-46.3$ & - & Lovis et al. (2013) & Argentina \\
\hline & $23.0-43.4$ & $51.5-58.3$ & - & Lovis et al. (2013) & Australia \\
\hline Deltamethrin & $8.3-97.7$ & - & & Beugnet and Chardonnet (1995) & New Caledonia \\
\hline Permethrin & - & $9.5^{*}$ & - & Miller et al. (2007b) & USA \\
\hline \multicolumn{6}{|l|}{ Macrocyclic lactones } \\
\hline \multirow[t]{5}{*}{ Ivermectin } & $7.0-10.2$ & - & $50.2-179.6$ & Perez-Cogollo et al. (2010a) & Mexico \\
\hline & $2.6-3.0$ & - & $9.5-6.5$ & Fernandez-Salas et al. (2012a) & Mexico \\
\hline & 7.1. & - & 5.0 & Rodriguez-Vivas et al. (2013) & Mexico \\
\hline & $1.8-4.6$ & - & - & Klafke et al. (2011) & Brazil \\
\hline & $1.3-1.9$ & - & - & Castro-Janer et al. (2011) & Uruguay \\
\hline \multicolumn{6}{|l|}{ Organophosphates } \\
\hline \multirow[t]{4}{*}{ Coumaphos } & $2.8-10.0$ & & & Li et al. (2003) & Mexico \\
\hline & 3.6 & 5.0 & 6.5 & Miller et al. (2005) & USA \\
\hline & 6.8 & - & 5.9 & Rodriguez-Vivas et al. (2013) & Mexico \\
\hline & $5.6-6.4$ & $7.5-16.0$ & - & Lovis et al. (2013) & Australia \\
\hline \multirow[t]{3}{*}{ Diazinon } & $6.3-34.4$ & & & Li et al. (2003) & Mexico \\
\hline & 7.1 & 11.7 & 17.7 & Miller et al. (2005) & USA \\
\hline & $1.3-5.4$ & $1.0-4.3$ & - & Lovis et al. (2013) & Argentina \\
\hline Chlorphyriphos & 1.5 & & 0.6 & Rodriguez-Vivas et al. (2013) & Mexico \\
\hline \multicolumn{6}{|l|}{ Amidines } \\
\hline \multirow[t]{5}{*}{ Amitraz } & $1.0-4.5$ & - & - & Li et al. (2004) & USA \\
\hline & & & 41.9 & Soberanes et al. (2002) & Mexico \\
\hline & $1.0-22.0$ & - & - & Rosado-Aguilar et al. (2008) & Mexico \\
\hline & 2.3 & - & 4.4 & Rodriguez-Vivas et al. (2013) & Mexico \\
\hline & $0.7-32.5$ & - & $0.1-4.3$ & Lovis et al. (2013) & Argentina \\
\hline
\end{tabular}

$R F_{50}$ resistance factor at $50 \%, R F_{90}$ resistance factor at $90 \%, R F_{99}$ resistance factor at $99 \%,-$ no available data, USA United States of America *In the $\mathrm{F}_{2}$

There are four potential mechanisms of resistance to amitraz: (1) octopamine/tyramine receptor insensitivity, (2) beta-adrenergic octopamine receptor $(B A O R)$ insensitivity, (3) elevated monoamine oxidase expression and (4) increased activity of ATP-binding cassette transporters (Jonsson et al. 2018). Baxter and Barker (1999) sequenced a putative octopamine receptor from amitraz resistant and susceptible R. microplus Australian strains and found no differences. However, as noted by Corley et al. (2012), the gene that was sequenced was more likely an octopamine-tyramine receptor.
Chen et al. (2007) reported mutations in amitraz-resistant $R$. microplus in the same octopamine-tyramine receptor as examined by Baxter and Barker (1999). Corley et al. (2013) subsequently sequenced the $B A O R$ gene and discovered a mutation in the first extracellular domain of the receptor that was predicted to result in an I61F substitution in amitrazresistant $R$. microplus. Recently, Baron et al. (2015) confirmed that the two SNPs in octopamine-tyramine receptor reported by Chen et al. (2007) were associated with amitraz resistance in the South African tick strain. Recently, Robbertse et al. 
(2016) evaluated the acaricide resistance status and the level of genetic diversity in a partially isolated $R$. microplus population in 12 dip stations in South Africa. Approximately half of the ticks sampled proved to be genotypically resistant to amitraz on the basis of the presence of the SNPs described by Chen et al. (2007). Jonsson et al. (2018) describe a group of mutations in the BAOR in the same region as the first detected mutation, all associated with elevated resistance to amitraz. At present, polymorphisms in octopamine-tyramine receptor and $B A O R$ have some potential for molecular diagnosis of amitraz resistance; however, the diversity of mutations suggests that no single polymorphism can be relied on.

In arthropods, $\gamma$-aminobutyric acid (GABA) is an inhibitory neurotransmitter at neuromuscular junctions and synapses in the central nervous system. Fipronil, dieldrin and isoxazoline chemical class (fluralaner) are reported to be antagonists of GABA-gated chloride channels in $R$. microplus (Ozoe et al. 2010). Mutations of the GABA gene of Drosophila melanogaster and Anopheles funestus have been reported (Wondji et al. 2011). Hope et al. (2010) reported mutations associated with dieldrin resistance in $R$. microplus. A mutation in the GABA-gated chloride channel gene was identified at position 868-9 and causes a Thr $\rightarrow$ Leu amino acid substitution.

The genotypic basis of resistance to MLs in arthropods has not been clarified (Rodriguez-Vivas et al. 2014a). Insensitivity of the GluCl receptor, which prevents drug binding to its target site, has been associated with ivermectin resistance in some nematodes and arthropods (Kwon et al. 2010). It has been suggested from molecular, pharmacokinetic, and biochemical studies that the most important molecules involved in detoxification of MLs are ATP-binding cassette (ABC) transporter proteins (Dermauw and Van Leeuwen 2014). The ABC transporter efflux pump is a defense mechanism against ivermectin in $R$. microplus (Pohl et al. 2012), and variation in the level of expression of the $A B C B 10$ gene has been associated with resistance to MLs in ticks (Pohl et al. 2012) and to other acaricides using in vitro approaches in cell cultures (Koh-Tan et al. 2016). However, despite the evidence of altered $A B C B 10$ expression in resistant populations, the genotypic genotypic basis of this variation is not known, and there are no useful molecular diagnostic tests for resistance to MLs.

\section{Correlation between genotypic and phenotypic resistance}

Strong correlations between the frequency of resistanceconferring alleles in samples of ticks and their resistance phenotype in a bioassay (have been reported for the para-sodium channel gene, for the octopamine gene and for the $B A O R)$. In Mexico, Rosario-Cruz et al. (2005) working with nine populations of $R$. microplus found a positive correlation (flumethrin $r^{2}=0.849$; cypermethrin $r^{2}=0.856$; deltamethrin $r^{2}=0.887$ ) between larval survival (using DD) and the percentage of the resistant allele of the sodium channel mutation known to be involved in SP resistance. Li et al. (2007) found a significant correlation $\left(r^{2}=0.827\right)$ between the permethrin resistance factor and allele frequency of the T2134A mutation in five laboratory strains of $R$. microplus. In a study carried out in Mexico, Rosario-Cruz et al. (2009) found that the presence of the T2134A mutation of $R$. microplus was associated with resistance to flumethrin, deltamethrin and cypermethrin. Rodriguez-Vivas et al. (2012b) studied the prevalence of pyrethroid resistance phenotype and genotype in $R$. microplus in Yucatan, Mexico, and found that the increasing presence of the resistance allele correlated well with increased levels of dose response to cypermethrin. RodriguezVivas et al. (2011) studied the phenotypic and genotypic changes in field populations of $R$. microplus in response to SP selection pressure. The authors found a strong correlation between the percentage of homozygous resistant ticks and the proportion of larval survival in three of four studied tick populations $\left(r^{2} \mathrm{~s}=>0.850\right)$, confirming that the T2134A mutation is a major cause of SP resistance in Mexico. In Australia, Morgan et al. (2009) and Jonsson et al. (2010a) studied field populations of $R$. microplus with synthetic pyrethroid resistance status and found close correlations between the parasodium channel gene mutations and survivorship in larval bioassays.

In Queensland, Australia, Corley et al. (2013) found a positive correlation between the frequency of the I61F-resistant homozygous genotype in the beta-adrenergic-like octopamine receptor and resistance of $R$. microplus to amitraz $(r=0.90)$.

\section{Cross-resistance and multiple resistance}

Cross-resistance is when the exposure of a population to one compound leads to the selection of adaptations that confer resistance to a different compound. Multiple resistance occurs when ticks develop resistance to two or more than two compounds by expressing multiple resistance mechanisms. Multiple resistances of different classes of acaricidels used to control ticks have become increasingly prevalent worldwide. Table 3 lists reports of crossresistance and multiple resistance in $R$. microplus to acaricide and ML in different parts of the word.

\section{Factors influencing the rate of emergence of resistance to acaricides}

The rate at which a resistant allele becomes established in the population and the time it takes for the control of ticks to break down is dependent upon (a) the frequency of the original mutation in the population before treatment, (b) the mode of inheritance of the resistant allele, (c) the proportion of the total tick population that is exposed to the acaricide, (d) the frequency of acaricide treatment and (e) 
Table 3 Cross and multiple resistance of $R$. microplus to conventional acaricide and ML reported worldwide

\begin{tabular}{|c|c|c|c|}
\hline $\begin{array}{l}\text { Field population or } \\
\text { laboratory strain (number) }\end{array}$ & $\begin{array}{l}\text { Acaricide or ML } \\
\text { (test used to diagnose resistance) }\end{array}$ & Country & Reference \\
\hline Ultimo strain & $\mathrm{SP}(\mathrm{LPT})+\mathrm{AM}(\mathrm{LPT})$ & Australia & $\begin{array}{l}\text { Kunz and Kemp } \\
\text { (1994) }\end{array}$ \\
\hline Coatzacoalco strain & $\mathrm{OP}(\mathrm{LPT})+\mathrm{SP}(\mathrm{LPT})$ & USA & $\begin{array}{l}\text { Miller et al. } \\
\text { (1999) }\end{array}$ \\
\hline Mora strain & $\mathrm{OP}(\mathrm{LPT})+\mathrm{SP}(\mathrm{LPT})$ & Mexico & $\begin{array}{l}\text { Redondo et al. } \\
\text { (1999) }\end{array}$ \\
\hline Montecitos strain & $\mathrm{OP}(\mathrm{LPT})+\mathrm{SP}(\mathrm{LPT})+\mathrm{AM}(\mathrm{AIT})$ & Colombia & $\begin{array}{l}\text { Benavides et al. } \\
\quad(2000)\end{array}$ \\
\hline Field populations & $\mathrm{AM}(\mathrm{LIT})+\mathrm{OP}(\mathrm{LPT})+\mathrm{SP}(\mathrm{LPT})$ & Mexico & $\begin{array}{l}\text { Rodriguez-Vivas } \\
\text { et al. (2007) }\end{array}$ \\
\hline Field populations & IVM (LIT) + PYZ (LIT) & Uruguay & $\begin{array}{l}\text { Castro-Janer } \\
\text { et al. (2011) }\end{array}$ \\
\hline Field populations & $\mathrm{OP}(\mathrm{LPT})+\mathrm{SP}(\mathrm{LPT})$ & Brazil & $\begin{array}{l}\text { Mendes et al. } \\
\quad(2011)\end{array}$ \\
\hline Field populations & $\begin{array}{l}\mathrm{OP}(\mathrm{LPT})+\mathrm{SP}(\mathrm{LPT})+\mathrm{AM}(\mathrm{AIT})+\mathrm{IVM} \\
\quad(\mathrm{LIT})\end{array}$ & Mexico & $\begin{array}{l}\text { Fernandez-Salas } \\
\text { et al. (2012b) }\end{array}$ \\
\hline Field populations & $\mathrm{SP}(\mathrm{AIT})+\mathrm{AM}(\mathrm{AIT})$ & Brazil & $\begin{array}{l}\text { Veiga et al. } \\
\quad(2012)\end{array}$ \\
\hline Field population & $\begin{array}{l}\mathrm{OP}(\mathrm{LPT})+\mathrm{SP}(\mathrm{LPT})+\mathrm{AM}(\mathrm{LIT})+\mathrm{IVM} \\
\quad(\mathrm{LIT})+\mathrm{PYZ}(\mathrm{LPT})\end{array}$ & Mexico & $\begin{array}{l}\text { Rodriguez-Vivas } \\
\text { et al. (2013) }\end{array}$ \\
\hline Santo Tomé strain & $\mathrm{SP}(\mathrm{AIT}, \mathrm{LTT})+\mathrm{AM}(\mathrm{AIT}, \mathrm{LTT})$ & Argentina & $\begin{array}{l}\text { Cutullé et al. } \\
\text { (2013) }\end{array}$ \\
\hline Field populations & SP (LTT) + PYZ (LTT) & $\begin{array}{l}\text { South } \\
\text { Africa }\end{array}$ & $\begin{array}{l}\text { Lovis et al. } \\
\text { (2013) }\end{array}$ \\
\hline Field populations & $\mathrm{OP}(\mathrm{LTT})+\mathrm{SP}(\mathrm{LTT})$ & Australia & $\begin{array}{l}\text { Lovis et al. } \\
\quad(2013)\end{array}$ \\
\hline Field populations & $\begin{array}{l}\mathrm{OP}(\mathrm{LPT})+\mathrm{SP}(\mathrm{LPT})+\mathrm{AM}(\mathrm{LPT})+\mathrm{IVM}(\mathrm{LI}) \\
\quad+\mathrm{PYZ}(\mathrm{LPT})+\text { Fluazuron }(\mathrm{AIT})\end{array}$ & Brazil & $\begin{array}{l}\text { Reck et al. } \\
\quad(2014)\end{array}$ \\
\hline Zamora strain & $\begin{array}{l}\text { OP }(\text { LPT, EST })+\mathrm{SP}(\mathrm{LPT})+\mathrm{AM}(\mathrm{LPT})+ \\
\quad \mathrm{PYZ}(\mathrm{LPT})\end{array}$ & Mexico & $\begin{array}{l}\text { Miller et al. } \\
\quad(2013)\end{array}$ \\
\hline Filed populations & $\begin{array}{l}\mathrm{OP}+\mathrm{SP}(\mathrm{LPT}), \mathrm{SP}+\mathrm{AM}+\mathrm{PYZ}(\mathrm{LPT}), \mathrm{OF}+ \\
\quad \mathrm{SP}+\mathrm{PYZ}(\mathrm{LPT})\end{array}$ & USA & $\begin{array}{l}\text { Busch et al. } \\
\quad(2014)\end{array}$ \\
\hline Field population & $\begin{array}{l}\mathrm{OP}(\mathrm{LPT})+\mathrm{SP}(\mathrm{LPT})+\mathrm{AM}(\mathrm{LIT})+\mathrm{IVM} \\
\quad(\mathrm{LIT})\end{array}$ & Mexico & $\begin{array}{l}\text { Fernandez-Salas } \\
\text { et al. (2012b) }\end{array}$ \\
\hline
\end{tabular}

$M L$ macrocyclic lactone, $O F$ organophosphates, $S P$ synthetic pyrethroids, $A M$ amidine, $I V M$ ivermectin, $P Y Z$ phenylpyrazoles, EST esterase, $L P T$ larval packet test, AIT adult immersion test, $L I T$ larval immersion test, $L T T$ larval tarsal test the rate of dispersal of resistant ticks into new areas. Emergence of resistance to acaricides can be seen as an evolutionary process, subject to the main drivers of population genetics: (1) mutation, (2) drift, (3) selection and (4) migration. Of these factors, mutation relates to the initial frequency of resistance-conferring alleles; selection is a function of the mode of inheritance, refugia, frequency and concentration; migration is dispersal. Drift (loss of rare alleles and fixation of common alleles at a locus) has not been investigated to any great extent in tick populations, but is likely to be particularly relevant to the genetics of tick strains maintained in culture and the genetics of outbreak populations in previously uninfested areas.

\section{Initial frequency of resistance-conferring alleles}

The initial frequency of resistance-conferring alleles in a population is one of the most important determinants of the rate of emergence of resistance when selection is applied (Roush and McKenzie 1987). It is expected that alleles that will confer resistance to any compound are already present at very low levels in the tick population before the introduction of a new acaricide. Estimates of initial frequencies of resistanceconferring alleles in naïve populations of arthropods range considerably, from $10^{-2}$ to $10^{-13}$ (Roush and McKenzie 1987; Gould et al. 1997). To confirm an initial frequency of $10^{-3}$ would require something between 1000 and 10,000 tests, 
which explains why empirical data from the field are scarce. Gould et al. (1997) used 2000 single-pair matings and a bioassay to detect alleles conferring resistance to BT toxin in Heliothis virescens, resulting in a high estimate of initial frequency of $1.5 \times 10^{-3}$. This high frequency was proposed to have arisen from prior exposure of the population to related compounds. No initial frequencies of resistance-conferring alleles for any acaricide compounds have been determined for R. microplus.

\section{Mode of inheritance}

The mode of inheritance of resistance in $R$. microplus is the subject of several relevant studies. An acaricide resistance phenotype may be inherited as a dominant, partially dominant or recessive character (ffrench-Constant and Roush 1990). However, these classifications are more complex than is initially apparent. This is nicely illustrated in a figure taken from Roush and McKenzie (1987) that shows the effect of bioassay concentration on the apparent mode of inheritance of resistance for a monogenic resistance mechanism (Fig. 1). In the field, things are messier than they are in the laboratory and the concentrations to which ticks are exposed vary widely. Hence, the mode of inheritance determined from laboratory bioassays may not reflect the mode of inheritance actually seen under field conditions. The mode of inheritance of SP compounds in the field has been reasonably well described. Early work (e.g. Tapia-Perez et al. 2003) suggested that resistance was polygenic, but more recent work (e.g. Rodriguez-Vivas et al. 2012b) has confirmed that most cases of resistance in the field can be attributed to one of four known allelic variants of the para-sodium channel gene (He et al. 1999; Morgan et al. 2009; Jonsson et al. 2010a; Stone et al. 2014). Based on reciprocal crosses of a susceptible and a resistant $R$. microplus strain, Aguilar-Tipacamu et al. (2008) evaluated the inheritance of SP resistance using the 'effective dominance of survival method' described by Bourguet et al. (2000). The authors found that pyrethroid resistance (cypermethrin, flumethrin and deltamethrin) is inherited as a partially dominant trait when the $R$. microplus female is resistant. However, when the male is resistant for flumethrin and deltamethrin, the resistance is inherited as complete recessive (partially dominant for cypermethrin). The molecular studies of Morgan et al. (2009) and Jonsson et al. (2010a) strongly suggest a recessive mode of inheritance for the phenotypes arising from these mutations, at least in standard bioassays of SP efficacy. Li et al. $(2004,2005)$ suggested that amitraz resistance was inherited as an incomplete recessive trait; however, FragosoSanchez et al. (2011) found that amitraz resistance in $R$. microplus is almost completely recessive; the work of Corley et al. (2013) with BAOR also indicated a recessive mode of inheritance for amitraz resistance.

\section{Selection intensity - field and laboratory studies}

Selection intensity for acaricide resistance is driven strongly by the frequency of acaricide applications and by the proportion of ticks that are untreated at any time when treatments are applied (Kunz and Kemp 1994). The proportion of ticks that are not exposed to any acaricide treatments is known as the refugia. Whereas many studies have been applied in the laboratory, relatively few have been conducted in the field. The following paragraphs briefly describe some studies on the application of selection pressure with the main classes of acaricide to R. microplus.

Organophosphates Under laboratory conditions, Harris et al. (1988) conducted a study to generate resistance in $R$. microplus to OPs. The authors selected for resistance to coumaphos by dipping groups of engorged $R$. microplus females in serial dilutions $(0.2,0.1,0.06,0.03$ and $0.01 \%$ of active ingredient) prepared from a commercial $50 \%$ flowable formulation of coumaphos. Surviving offspring from females treated with the most concentrated coumaphos dilutions were retained for reproduction. This method of selection was used for the three generations in the laboratory; then, the authors changed to a technique in which larvae from a single female were selected and treated with coumaphos (0.1 to $1 \%)$. During 12 generations with selection process, the studied strain of $R$. microplus became 38 times more resistant to coumaphos than the susceptible reference strain. Working with a resistant strain ('Tuxpan'), Wright and Ahrens (1989) made selection pressure in three generations by dipping groups of engorged females in dilutions of $42 \%$ (active ingredient) flowable formulation of coumaphos. They found that Tuxpan strain became more resistant to coumaphos as the generations proceeded. In another study conducted by Davey et al. (2003), larvae from $F_{1}$ generation and all subsequent generations up to the $\mathrm{F}_{14}$ generation were selectively exposed to coumaphos ( 0.2 to $0.45 \%$ ) to maintain or increase the amount of OP resistance in the strain. The $\mathrm{F}_{2}$ resulted in an estimated $\mathrm{LC}_{50}$ of $0.623 \%$, whereas ticks in the $\mathrm{F}_{14}$ generation resulted in an estimated $\mathrm{LC}_{50}$ of $0.688 \%$. Comparison of these results with the OP-susceptible reference strain revealed that the $\mathrm{F}_{2}$ generation of OP-resistant ticks was approximately 12 times more resistant to coumaphos than the OP-susceptible strain, whereas the $\mathrm{F}_{14}$ generation was approximately 13 times more resistant to coumaphos than the susceptible strain. Therefore, although the 12 successive generations of continuous selective exposure to coumaphos maintained the RF, it did not substantially increase the RF. Davey et al. (2004) worked with the same OP-resistant strain and applying pressure with coumaphos treatments during all 22 subsequent generations and found that the level of resistance did not significantly increase. 
Amitraz In laboratory conditions, Li et al. (2004) applied selection pressure using amitraz on larvae of a R. microplus strain ('Santa Luiza'). The strain was challenged with different concentrations of amitraz and responded to selection quickly. The RF increased from 13.3 in $F_{1}$ to 154 in $F_{6}$. Although resistance decreased sharply without selection in the following generations $\left(F_{8}=68.72\right)$ and at low dose pressure of amitraz $\left(\mathrm{F}_{9}=50.7, \mathrm{~F}_{12}=49.43\right)$. In the Mexican tropics, RosadoAguilar et al. (2008) treated three field populations of $R$. microplus with amitraz. After 15 months of amitraz selection pressure, the three populations increased their RFs (from 1 to 13 , from 1 to 22 and from 2 to 6). Fragoso-Sanchez et al. (2011) described the genetics of amitraz resistance evolution in R. microplus. They studied three Mexican tick strains, one susceptible to all acaricides and two amitraz resistant. Larvae were reared on isolated heifers and maintained nine generations in laboratory conditions. From each generation and each strain, the amitraz $\mathrm{LC}_{50}$ was chosen as the selection concentration for each strain. After 10 generations, the RFs increased 1-10, 4-60 and 10-107 for the susceptible and resistant (Palenque strain) and resistant (San Alfonso strain), respectively. In Queensland, Australia, Corley et al. (2013) found an increase over time in the frequency of the resistant homozygous I61F genotype in farms on which amitraz was used regularly, contrasted with relatively static frequency of the I61F homozygous genotype in farms on which amitraz was never used. In this study, the authors showed a strong association between a polymorphism in a highly conserved region of the $\mathrm{Rm} \beta \mathrm{AOR}$ gene of $R$. microplus and resistance to amitraz in the larval packed test and demonstrated that the mutation is selected for by treatment with amitraz over seven generations in the field.

Synthetic pyrethroids In a controlled field trial, Coetzee et al. (1987) reported rapid onset and development of fenvalerate in $B$. decoloratus. The selection for resistance occurred during an 18 -month period (equivalent to five to six generations). Davey and George (1998) selected a R. microplus strain for resistance to permethrin by treating larvae with increasing doses (range, $0.05-0.35 \%$ ) through successive generations (generations $\mathrm{F}_{2-}$ $\left.\mathrm{F}_{7}\right)$. At the beginning of the selection process $\left(\mathrm{F}_{2}\right)$, the SPresistant strain was 5.4 times more resistant to permethrin than the SP-susceptible strain, and the level of resistance increased in each successive generation of the SP-resistant strain, reaching a $R F$ of 20.9 in the $F_{7}$ generation. In a prospective controlled intervention field study, Rodriguez-Vivas et al. (2011) measured the resistance phenotype and genotype of R. microplus on 11 farms in Yucatan, Mexico, where cypermethrin was used regularly. On five farms, cypermethrin continued to be used, and on six, it was substituted with amitraz used every 30-45 days. After 24 months of continued selection pressure with cypermethrin, the RF increased from 2 -fold to 125 -fold. The frequency of the resistance-conferring allele (T2134A mutation) increased on all five farms from a starting range of $6-47 \%$ to a range of $66-95 \%$ after 24 months. On six farms treated with amitraz, neither the SP RFs nor the frequency of the T2134A allele changed significantly. It was concluded that SP selection pressure on a field population of $R$. microplus rapidly generated cypermethrin resistance with increases of RF which correlated with increased frequencies of the resistance allele. In populations in which cypermethrin was substituted, other acaricide class (amitraz) RFs and frequencies of the resistance allele remained stable over 24 months.

Macrocyclic lactones At present, the only study reporting selection intensity for ivermectin resistance was conducted in Brazil by Klafke et al. (2010). The authors used four methodologies to select the ivermectin-resistant strain: (1) cattle infestation with IVM-treated larvae, (2) with larvae from IVM-treated adult female ticks, (3) with larvae from IVMtreated adult female ticks on an IVM-treated host and (4) with larvae obtained from IVM-treated females that produced eggs with a high eclosion rate. After ten generations of R. microplus, using these methods combined the RF increased from 1.37 to 8.06 .

\section{Risk factors for acaricide resistance derived from field studies}

Jonsson et al. (2000) and Bianchi et al. (2003) identified several factors associated with increased probability of resistance to different acaricides. The risk factors differed among the acaricides tested, frequency of application, type of application, farm localization, fly control and grazing management. Rodriguez-Vivas et al. (2006a) found in the Mexican tropics high probability of $R$. microplus SP resistance on farms where acaricides were applied $\geq 6$ times in 1 year $(\mathrm{OR}=4.83)$. This finding is in agreement with Sutherst (1979), which indicated stronger selection for resistance when six acaricide applications were made per year, compared with four or five applications per year. Similar results were found by Jonsson et al. (2000) who found higher probability of tick resistance to cypermethrin, deltamethrin and flumethrin when acaricides were used $>5$ times/year. However, it was noted that the first response of many farmers to a problem of acaricide resistance is to increase the frequency of treatment, making it difficult to distinguish between cause and effect in observational, crosssectional studies. Fernandez-Salas et al. (2012a) found that on cattle farms of Veracruz, Mexico, those which used ML $\geq 4$ times per year were more likely to develop $R$. microplus resistant to ivermectin $(\mathrm{OR}=13.0)$. Rodriguez-Vivas et al. (2006a) also found in farms that used another tick control program were associated with higher probability of $R$. microplus presenting flumethrin, deltamethrin and cypermethrin resistance $(\mathrm{OR}=5.9)$. 


\section{Persistence of insecticide resistance}

Whereas selection pressure with an acaricide is expected to increase the frequency of resistant genotypes in a population, it is possible that removal of the selection pressure might be followed by a reduction in the frequency of the resistant genotypes, particularly if these genotypes are otherwise of lower reproductive fitness than the acaricide-susceptible genotypes in the absence of selection. Fitness costs associated with pesticide resistance have been documented in many pest species (Coustau et al. 2000; Oliveira et al. 2007). The reproductive fitness of $R$. microplus strains resistant to OPs, SPs or amitraz was compared to an acaricide-susceptible strain to determine whether the acquisition of resistance affected reproductive fitness in the resistant strains (Davey et al. 2006). The authors found that the OP-resistant strain produced 30\% fewer eggs than the susceptible strain indicating that the acquisition of resistance placed the OP resistant at a selective disadvantage relative to the susceptible strain. The fitness cost of SP and amitraz-resistant strains was not found. However, Soberanes et al. (2002) reported in Mexico that the level of resistance of R. microplus to amitraz in the San Alfonso strain decreased from 42-fold to 10 -fold after six generations on laboratory condition without amitraz selection. In field populations of R. microplus, Rodriguez-Vivas et al. (2005) found persistent resistance to OP for more than 4 years. Rodriguez-Vivas et al. (2011) used a tactical management strategy to reduce the cypermethrin resistance on field populations of $R$. microplus in the Mexican tropics. Cattle with pyrethroid-susceptible ticks were introduced into two farms with pyrethroidresistant population over 31 months. This management caused significant reduction in $\mathrm{RFs}$ in farm $1\left(\mathrm{LC}_{50}=\right.$ from 14.2 to $1.3)$ and farm $2\left(\mathrm{LC}_{50}=\right.$ from 12.3 to 1.6). In farm 1 and farm 2 , the frequency of the R allele (T2134A mutation) decreased from 56.7 to $15.5 \%$ and from 57.8 to $18.3 \%$, respectively. In Queensland, Australia, Corley et al. (2013) studied the evolution of resistance to amitraz in $R$. microplus in field condition and tested the association between amitraz resistance and the frequency of the I61F mutation. Over the 3-year field study, there was some evidence of loss of resistance to amitraz in populations of ticks on farms where cattle were treated with spinosad.

\section{International reports of acaricide resistance}

Acaricide resistance is generally less of a problem in multi-host than single-host ticks, and the development of acaricide resistance in several countries has been faster in R. microplus compared to multi-host ticks (RodriguezVivas 2008; Rodriguez-Vivas et al. 2012a, 2014a, c). Since the first report of the development of resistance in R. microplus populations to arsenicals in Australia in
1937, the progressive evolution of resistance in ticks affecting cattle to almost all of the available acaricides has frustrated the efforts of cattle producers to manage ticks and tick-borne diseases affecting their animals (Guerrero et al. 2014). Selected records of the geographic distribution of acaricide resistance in $R$. microplus worldwide are listed in Table 4 and depicted in Fig. 2.

\section{Strategies to minimize the development, progression and impact of resistance}

The main strategies to delay the emergence of acaricide resistance include reduced frequency of application, modification of dose or concentration, use of mixtures, use of synergists, rotation between acaricide classes having differing mechanisms of action, preservation of untreated refugia and the application of biosecurity protocols to prevent introduction of resistant ticks (George et al. 2004). To reduce the development of resistance, the knowledge of the tick species present and the resistance status should be considered before the selection of acaricides. Cases of field resistance should be confirmed in the laboratory.

\section{Reducing frequency of application}

Any effective non-acaricidal control agent that can be applied to control ticks should reduce the requirement for acaricide use and therefore reduce selection pressure on acaricides. Commonly used or discussed control methods include manual removal, selection of cattle with high resistance to infestation, use of plants and plant extracts, vaccination and biological control agents (Rodriguez-Vivas et al. 2014b). These approaches are all discussed in detail below.

\section{Synergized pesticides and pesticide mixture formulations}

Synergism between different groups of ectoparasiticides has been used in several countries to control insects and ticks for many years (Li et al. 2007; Barré et al. 2008; Rodriguez-Vivas et al. 2013). Knowles (1982) demonstrated that amitraz and chlordimeform can act as synergists of OC, OP, carbamate and SP insecticides. Subsequent publications confirmed the synergism of amitraz and pyrethroids against insects and ticks (Usmani and Knowles 2001; Li et al. 2007), amitraz and fipronil against ticks (Prullage et al. 2011) and pyrethroids and neonicotinoids against mosquitoes (Ahmed and Matsumura 2012). Under laboratory conditions, Li et al. (2007) showed that adding amitraz to permethrin led to a strong increase in larval mortality of a highly pyrethroidresistant strain of $R$. microplus. The synergism between deltamethrin and amitraz was subsequently confirmed in a field trial on a farm in New Caledonia (Barré et al. 2008). 
Table 4 Selected records of the geographic distribution of acaricide resistance in $R$. microplus worldwide

\begin{tabular}{|c|c|c|c|c|}
\hline $\begin{array}{l}\text { Continent/ } \\
\text { country }\end{array}$ & Reference & Acaricide or ML compound & Tick specie & Test \\
\hline \multicolumn{5}{|l|}{ America } \\
\hline \multirow[t]{2}{*}{ USA } & Miller et al. (2007b) & Permethrin & R. microplus & LPT \\
\hline & Busch et al. (2014) & $\begin{array}{l}\text { Coumaphos, permethrin, amitraz, } \\
\text { ivermectin, fipronil }\end{array}$ & R. microplus & LPT \\
\hline \multicolumn{5}{|c|}{ 20 } \\
\hline & Ortiz et al. (1995) & $\begin{array}{l}\text { Dieldrin, lindane, coumaphos, } \\
\text { diazinon, dioxathion, dimethoate, } \\
\text { ethion, } \\
\text { cypermethrin, deltamethrin, } \\
\text { cypermethrin }\end{array}$ & R. microplus & LPT \\
\hline & Fragoso et al. (1995) & Amitraz & R. microplus & LPT \\
\hline & Soberanes et al. (2002) & Amitraz & R. microplus & LIT \\
\hline & Li et al. (2004) & Carbaryl & R. microplus & LPT \\
\hline & \multirow{2}{*}{$\begin{array}{l}\text { Rodriguez-Vivas et al. } \\
\text { (2006a) }\end{array}$} & Diazinon, coumaphos, chlorfenvinphos & R. microplus & LPT \\
\hline & & Flumethrin, deltamethrin, cypermethrin & R. microplus & LIT \\
\hline & $\begin{array}{l}\text { Rodriguez-Vivas et al. } \\
\text { (2006b) }\end{array}$ & Amitraz & R. microplus & LIT \\
\hline & \multirow{2}{*}{$\begin{array}{l}\text { Rodriguez-Vivas et al. } \\
\text { (2007) }\end{array}$} & Diazinon, coumaphos, chlorfenvinphos & R. microplus & LPT \\
\hline & & Flumethrin, deltamethrin, cypermethrin & R. microplus & LIT \\
\hline & $\begin{array}{l}\text { Rosado-Aguilar et al. } \\
\text { (2008) }\end{array}$ & Amitraz & R. microplus & LIT \\
\hline & $\begin{array}{l}\text { Perez-Cogollo et al. } \\
\quad(2010 \mathrm{a})\end{array}$ & Ivermectin & R. microplus & LIT \\
\hline & $\begin{array}{l}\text { Perez-Cogollo et al. } \\
\text { 2010b) }\end{array}$ & Ivermectin & R. microplus & LIT \\
\hline & $\begin{array}{l}\text { Rodriguez-Vivas et al. } \\
\text { (2011) }\end{array}$ & Cypermethrin & R. microplus & LPT \\
\hline & $\begin{array}{l}\text { Olivares-Pérez et al. } \\
\text { (2011) }\end{array}$ & $\begin{array}{l}\text { Amitraz, flumethrin, deltamethrin, } \\
\text { cypermethrin, clorpyriphos, } \\
\text { coumaphos, diazinon }\end{array}$ & R. microplus & LPT, LIT \\
\hline & \multirow{2}{*}{$\begin{array}{l}\text { Fernandez-Salas et al. } \\
\quad(2012 \mathrm{c})\end{array}$} & Cypermethrin & R. microplus & LPT \\
\hline & & Amitraz & R. microplus & LIT \\
\hline & \multirow[t]{2}{*}{$\begin{array}{l}\text { Fernandez-Salas et al. } \\
\qquad(2012 b)\end{array}$} & $\begin{array}{l}\text { Diazinon, flumethrin, } \\
\text { deltamethrin, cypermethrin }\end{array}$ & R. microplus & LPT \\
\hline & & Ivermectin & R. microplus & LIT \\
\hline & Miller et al. (2013) & Fipronil & R. microplus & LPT \\
\hline & \multirow{2}{*}{$\begin{array}{l}\text { Rodriguez-Vivas et al. } \\
\text { (2013) }\end{array}$} & Ivermectin, amitraz & R. microplus & LIT \\
\hline & & $\begin{array}{l}\text { Chlorpyrifos, coumaphos, } \\
\text { cypermethrin, permethrin, fipronil }\end{array}$ & R. microplus & LPT \\
\hline \multirow[t]{4}{*}{ Argentina } & Mangold et al. (2004) & Flumethrin & R. microplus & LPT \\
\hline & Cutullé et al. (2013) & Amitraz, cypermetrin, flumethrin & R. microplus & AIT, LTT \\
\hline & Lovis et al. (2013) & Amitraz, cypermethrin, flumethrin & R. microplus & LTT \\
\hline & Cutullé et al. (2013) & Amitraz, deltamethrin & R. microplus & AIT, LTT \\
\hline $\begin{array}{l}\text { República } \\
\text { Dominicana }\end{array}$ & Hagen et al. (1999) & Deltamethrin, flumethrin, cyfluthrin & R. microplus & LPT \\
\hline Jamaica & $\begin{array}{l}\text { Rawlins and Mansingh } \\
\text { (1978) }\end{array}$ & Carbaryl, lindane, chlorfenvinphos & R. microplus & LIT \\
\hline \multirow[t]{2}{*}{ Cuba } & \multirow[t]{2}{*}{ Valdez et al. (1999) } & Chlorfenvinphos & R. microplus & LPT \\
\hline & & Cyamizol & R. microplus & AIT \\
\hline Venezuela & Coronado (1999) & Amitraz & R. microplus & AIT \\
\hline Guatemala & Hagen et al. (1999) & Deltamethrin, flumethrin, cyfluthrin & R. microplus & LPT \\
\hline Honduras & Hagen et al. (1999) & Deltamethrin, flumethrin, cyfluthrin & R. microplus & LPT \\
\hline El Salvador & Hagen et al. (1999) & Flumethrin & R. microplus & LPT \\
\hline
\end{tabular}


Table 4 (continued)

\begin{tabular}{|c|c|c|c|c|}
\hline $\begin{array}{l}\text { Continent/ } \\
\text { country }\end{array}$ & Reference & Acaricide or ML compound & Tick specie & Test \\
\hline \multirow[t]{2}{*}{ Panama } & Hagen et al. (1999) & Flumethrin & R. microplus & LPT \\
\hline & Torrijos et al. (2015) & Cypermethrin & R. microplus & LPT \\
\hline \multirow[t]{3}{*}{ Costa Rica } & Hagen et al. (1999) & Flumethrin & R. microplus & LPT \\
\hline & $\begin{array}{l}\text { Alvarez and Hernandez } \\
\text { (2010) }\end{array}$ & $\begin{array}{l}\text { Chlorpyrifos, coumaphos, flumethrin, } \\
\text { deltamethrin, ivermectin }\end{array}$ & R. microplus & LPT \\
\hline & & Amitraz & R. microplus & LIT \\
\hline \multirow[t]{8}{*}{ Colombia } & Benavides et al. (2000) & $\begin{array}{l}\text { Cypermethrin, deltamethrin, } \\
\text { coumaphos, } \\
\text { clhorfenvinphos, diazinon, amitraz }\end{array}$ & R. microplus & LIT \\
\hline & & Amitraz & R. microplus & AIT \\
\hline & Diaz and Vallejo (2013) & Cypermethrin & R. microplus & AIT \\
\hline & Lopez-Arias et al. (2014) & Cypermetrhrin, amitraz & R. microplus & AIT \\
\hline & Araque et al. (2014) & Amitraz, ethion & R. microplus & AIT \\
\hline & Puerta et al. (2015) & Cypermethrin, amitraz & R. microplus & AIT \\
\hline & Villar et al. (2016a) & Ivermectin & R. microplus & LIT \\
\hline & Villar et al. (2016b) & Deltamethrin, amitraz, chlorpyrifos & R. microplus & AIT \\
\hline Bolivia & $\begin{array}{l}\text { Villarroel-Alvarez et al., } \\
2006\end{array}$ & Flumethrin, deltamethrin, cypermethrin & R. micropus & LPT \\
\hline \multirow[t]{5}{*}{ Uruguay } & Castro-Janer et al. (2009) & Fipronil & R. microplus & LIT \\
\hline & Castro-Janer et al. (2011) & Ivermectin & R. microplus & LIT \\
\hline & Cuore and Solari (2014) & $\begin{array}{l}\text { Ethion, cipermethrin, amitraz, fipronil, } \\
\text { ivermectin }\end{array}$ & R. microplus & LPT, LIT \\
\hline & Castro-Janer et al. (2015) & Fipronil & R. microplus & LIT \\
\hline & & Lindane & R. microplus & LPT \\
\hline \multirow[t]{16}{*}{ Brazil } & $\begin{array}{l}\text { Martins and Furlong } \\
\text { (2001) }\end{array}$ & Doramectin, moxidectina & R. microplus & In vivo \\
\hline & Li et al. (2004) & Amitraz & R. microplus & LPT \\
\hline & Klafke et al. (2006) & Ivermectin & R. microplus & LIT \\
\hline & Mendes et al. (2007) & $\begin{array}{l}\text { Cypermethrin, deltamethrin, } \\
\text { chlorpyriphos }\end{array}$ & R. microplus & LPT \\
\hline & Castro-Janer et al. (2010) & Fipronil & R. microplus & LIT, LPT \\
\hline & Klafke et al. (2010) & Ivermectin & R. microplus & LIT \\
\hline & Klafke et al. (2011) & Ivermectin & R. microplus & LIT \\
\hline & Andreotti et al. (2011) & $\begin{array}{l}\text { Alpha-cypermethrin, cypermethrin, } \\
\text { amitraz }\end{array}$ & R. microplus & AIT \\
\hline & Mendes et al. (2011) & $\begin{array}{l}\text { Deltamethrin, chlorpyriphos, } \\
\text { cypermethrin }\end{array}$ & R. microplus & LPT \\
\hline & Reck et al. (2014) & $\begin{array}{l}\text { Chlorpyriphos, amitraz, cypermethrin, } \\
\text { fipronil }\end{array}$ & R. microplus & LPT \\
\hline & & Ivermectin & R. microplus & LIT \\
\hline & & Fluazuron & R. microplus & AIT \\
\hline & Klafke et al. (2016) & Amitraz & R. microplus & LPT \\
\hline & & Chlorpyriphos, cypermethrin & R. microplus & LPT \\
\hline & & Fipronil, ivermectin & R. microplus & LIT \\
\hline & & Chlorpyriphos, cypermethrin & R. microplus & AIT \\
\hline \multicolumn{5}{|l|}{ Oceania } \\
\hline \multirow[t]{4}{*}{ New Caledonia } & Brun et al. (1983) & Ethion & R. microplus & LPT \\
\hline & $\begin{array}{l}\text { Beugnet and Chardonnet } \\
\text { (1995) }\end{array}$ & Fenvalerate, deltamethrin, flumethrin & R. microplus & LPT \\
\hline & Bianchi et al. (2003) & Deltamethrin, ethion & R. microplus & LPT \\
\hline & Ducornez et al. (2005) & Amitraz & R. microplus & LPT \\
\hline Australia & Stone and Webber (1960) & BHC, DDT, dieldrin & R. microplus & LIT, AIT \\
\hline
\end{tabular}


Table 4 (continued)

\begin{tabular}{|c|c|c|c|c|}
\hline $\begin{array}{l}\text { Continent/ } \\
\text { country }\end{array}$ & Reference & Acaricide or ML compound & Tick specie & Test \\
\hline & Stone and Meyers (1957) & Dieldrin & R. microplus & LIT, AIT \\
\hline & Shaw (1966) & $\begin{array}{l}\text { Carbophenothion, dioxathion, diazinon, } \\
\text { parathion, carbaryl }\end{array}$ & R. microplus & LIT \\
\hline & Nolan et al. (1989) & Cypermethrin, cyhalothrin & R. microplus & LIT, AIT \\
\hline & Roulston et al. (1981) & $\begin{array}{l}\text { Dimethoate, dioxathion, coumaphos, } \\
\text { cyanophos, chlorpyrifos, dieldrin, } \\
\text { DDT }\end{array}$ & R. microplus & \\
\hline & Jonsson and Hope (2007) & Amitraz & R. microplus & LPT \\
\hline & Lovis et al. (2013) & Flumethrin, cypermethrin, pyriprol & R. microplus & LTT \\
\hline \multicolumn{5}{|l|}{ Asia } \\
\hline \multirow[t]{10}{*}{ India } & $\begin{array}{l}\text { Chaudhuri and Naithani } \\
\text { (1964) }\end{array}$ & $\mathrm{BHC}$ & R. microplus & LIT, AIT \\
\hline & Kumar et al. (2011) & Diazinon & R. microplus & ALT \\
\hline & Sharma et al. (2012) & Deltamethrin, cypermethrin & R. microplus & LPT, AIT \\
\hline & Shyma et al. (2013) & Deltamethrin, cypermethrin, diazinon & R. microplus & LIT, AIT \\
\hline & Singh et al. (2014) & Cypermethrin & R. microplus & AIT \\
\hline & Jyoti Singh et al. (2014) & Malathion & R. microplus & AIT \\
\hline & Singh et al. (2015) & Amitraz & R. microplus & AIT \\
\hline & Ghosh et al. (2015) & Deltamethrin, diazinon & R. microplus & AIT \\
\hline & Shyma et al. (2015) & Deltamethrin, fipronil, flumethrin & R. microplus & AIT, LPT \\
\hline & Gaur et al. (2016) & Deltamethrin, diazinon & R. microplus & LPT, AIT \\
\hline \multirow[t]{3}{*}{ Iran } & Enayati et al. (2009) & Propetamphos & R. bursa & LPT \\
\hline & Ziapour et al. (2016a) & Cypermethrin, lambda-cyhalothrin & R. annulatus & LPT \\
\hline & Ziapour et al. (2016b) & Cypermethrin, lambda-cyhalothrin & R. bursa & LPT \\
\hline \multicolumn{5}{|l|}{ Africa } \\
\hline \multirow[t]{7}{*}{ Ethiopia } & \multirow{2}{*}{$\begin{array}{l}\text { Regassa and de Castro } \\
\text { (1993) }\end{array}$} & Toxaphene & R. decoloratus & LPT \\
\hline & & Toxaphene & R. evertsi evertsi & LPT \\
\hline & \multirow[t]{2}{*}{ Yilma et al. (2001) } & $\begin{array}{l}\text { Dieldrine, diazinon, chlorfenvinphos, } \\
\text { coumaphos }\end{array}$ & B. decoloratus & LPT \\
\hline & & Coumaphos & R. evertsi evertsi & LPT \\
\hline & Feyera et al. (2015) & Diazinon & R. pulchellus & TIT \\
\hline & \multirow[t]{2}{*}{ Jobre et al. (2001) } & $\begin{array}{l}\text { Dieldrine, diazinon, clorfenvinphos, } \\
\text { coumaphos }\end{array}$ & B. decoloratus & LPT \\
\hline & & Coumaphos & R. evertsi evertsi & LPT \\
\hline Zimbabwe & Mazhowu (1995) & $\begin{array}{l}\text { Dioxathion, flumethrin, cypermethrin, } \\
\text { deltamethrin }\end{array}$ & R. decoloratus & LPT \\
\hline Ghana & Kaljouw (2009) & Amitraz & Rhipicephalus ssp. & LPT \\
\hline \multirow[t]{2}{*}{ Tanzania } & Kagaruki (1991) & Dieldrin, lindane & $\begin{array}{l}\text { R. microplus, } R \text {. decoloratus, } R \text {. evertsi evertsi, } \\
\quad \text { R. appendiculatus }\end{array}$ & LPT \\
\hline & $\begin{array}{l}\text { Lourens and Tatchell } \\
\text { (1979) }\end{array}$ & Toxaphene, BHC, dieldrin & R. evertsi evertsi & LPT \\
\hline Benin & Adehan et al. (2016) & $\begin{array}{l}\text { Alpha-cypermethrin, deltamethrin, } \\
\text { amitraz }\end{array}$ & R. microplus & LPT \\
\hline \multirow[t]{7}{*}{ South Africa } & Baker and Shaw (1965) & Toxaphene, lindane & R. appendiculatus & $\begin{array}{l}\text { LIT, AIT, } \\
\text { NIT }\end{array}$ \\
\hline & \multirow[t]{2}{*}{ Ntondini et al. (2008) } & Amitraz, cypermethrin, chlorfenvinphos & R. microplus & LIT \\
\hline & & Chlorfenvinphos & R. evertsi evertsi & LIT \\
\hline & Baron et al. (2015) & Amitraz & R. microplus & LPT \\
\hline & Mekonnen et al. (2002) & Cypermethrin, chlorfenvinphos & R. decoloratus & LIT \\
\hline & \multirow[t]{2}{*}{ Mekonnen et al. (2003) } & Chlorfenvinphos, cypermethrin & R. decoloratus & $\begin{array}{l}\text { RET, ELT, } \\
\text { LIT }\end{array}$ \\
\hline & & Amitraz & R. decoloratus & RET, ELT \\
\hline
\end{tabular}


Table 4 (continued)

\begin{tabular}{|c|c|c|c|c|}
\hline $\begin{array}{l}\text { Continent/ } \\
\text { country }\end{array}$ & Reference & Acaricide or ML compound & Tick specie & Test \\
\hline & & Chlorfenvinphos & R. decoloratus & LIT \\
\hline & & Permethrin & R. decoloratus & RET \\
\hline & Lovis et al. (2013) & Pyriprol, cypermethrin, fenvalerate & R. microplus & LTT \\
\hline & Coetzee et al. (1987) & Fenvalerate & R. decoloratus & LIT, AIT \\
\hline \multirow[t]{4}{*}{ Zambia } & Luguru et al. (1987) & $\begin{array}{l}\text { Dimethoate, dioxathion, } \\
\text { chlorfenvinphos }\end{array}$ & R. appendiculatus & LPT \\
\hline & & $\begin{array}{l}\text { Dieldrin, dimethoate, dioxathion, } \\
\text { chlorfenvinphos }\end{array}$ & R. decoloratus & LPT \\
\hline & $\begin{array}{l}\text { Matthewson and } \\
\text { Blackman (1980) }\end{array}$ & $\begin{array}{l}\text { Dioxathion, toxaphene, } \\
\text { chlorfenvinphos }\end{array}$ & R. decoloratus & LPT \\
\hline & Muyobela et al. (2015) & Amitraz, cypermethrin & R. microplus, $R$. appendiculatus & LPT \\
\hline Uganda & Vudriko et al. (2016) & $\begin{array}{l}\text { Chlorfenvinphos, amitraz, } \\
\text { cypermethrin, deltamethrin }\end{array}$ & R. appendiculatus $R$. decoloratus & LPT \\
\hline Kenya & Baker and Shaw (1965) & Toxaphene, lindane & R. appendiculatus & $\begin{array}{l}\text { LIT, AIT, } \\
\quad \text { NIT }\end{array}$ \\
\hline
\end{tabular}

$M L$ macrocyclic lactone, RET reproductive estimate test, ELT egg-laying test, TIT ticks of equal size are immersed, NIT nymph immersion test, $R$. Rhipicephalus

The main synergists that have been used as ixodicide action potentiators for tick control are piperonyl butoxide (PBO) (a cytochrome P450 monooxygenase inhibitor), triphenylphosphate (TPP, an esterase inhibitor), diethyl maleate (DEM, an inhibitor of glutathione-S-transferases) and verbutin (an inhibitor of certain cytochrome P450 isoforms) (Li et al. 2007). Metabolic enzyme defense systems including the cytochrome P450 monooxygenases and esterases are present at a 'baseline level' in arthropods. In resistant arthropods, their activity can be elevated to detoxify pesticides (Young et al. 2006). $\mathrm{Li}$ et al. (2010) demonstrated that the use of a reduced PBO and verbutin concentrations potentiates the action of permethrin, coumaphos and amitraz. The verbutin demonstrated greater synergism than PBO to control $R$. microplus larvae resistant to coumaphos (synergism index $(\mathrm{SI})=1.5-6.0$ vs. $0.9-1.6$ ) and amitraz ( $\mathrm{SI}=1.8-1.5$ vs. $0.9-2.5$ ), but similar synergism for permethrin ( $\mathrm{SI}=2.1-4.4$ vs. 2.1-3.6). Rodriguez-Vivas et al. (2013) evaluated the efficacy of cypermethrin, amitraz and $\mathrm{PBO}$ mixtures, through in vitro laboratory bioassays and in vivo on-animal efficacy trials, for the control of resistant R. microplus on cattle in the Mexican tropics. The authors showed that the mixture of cypermethrin + amitraz + PBO

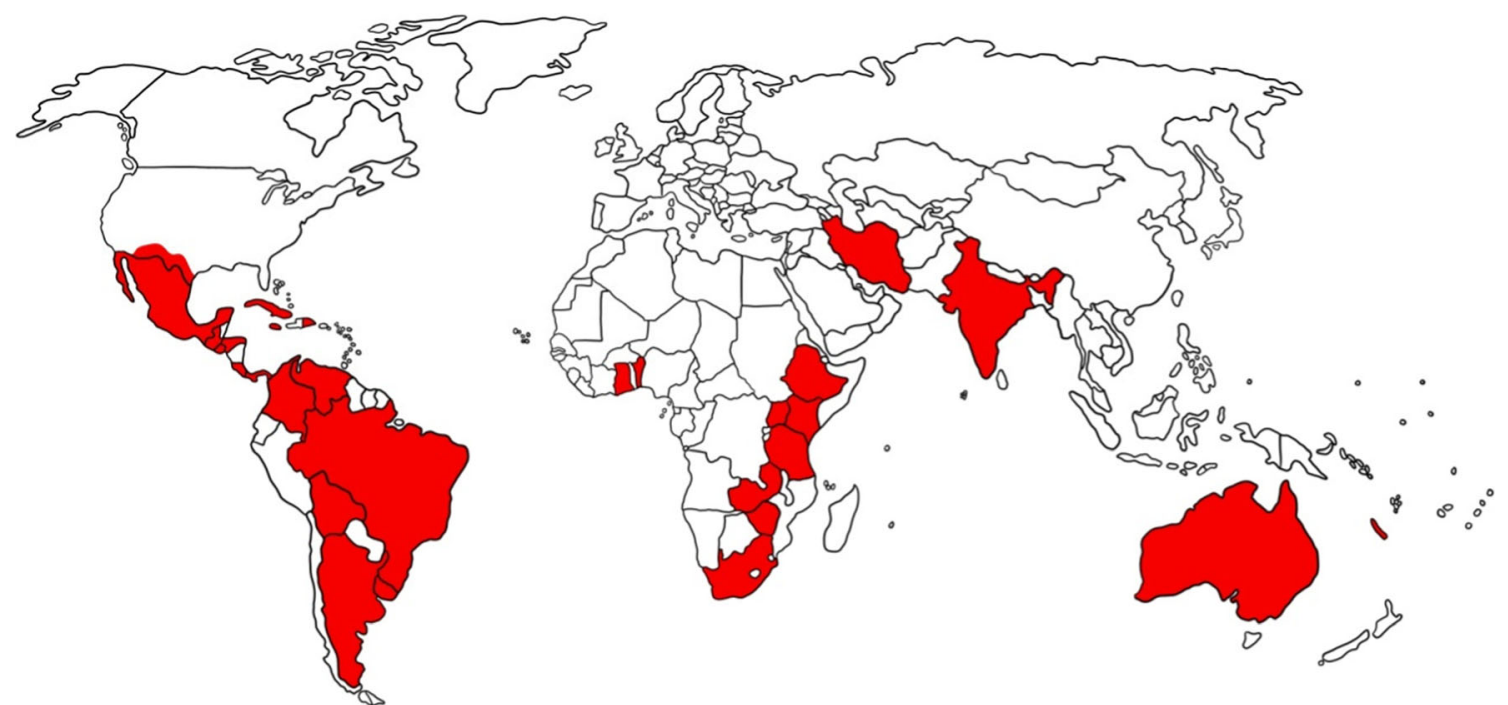

Fig. 2 Geographic distribution of acaricide resistance in Rhipicephalus ticks worldwide (R. microplus: the USA, Mexico, Jamaica, Republica Dominicana, Cuba, Guatemala, Honduras, El Salvador, Panama, Costa Rica, Colombia, Venezuela, Bolivia, Uruguay, Brazil, Argentina, Australia, New Caledonia, India, Ira, Benin, Tanzania, South Africa and
Zambia; $R$. bursa: India and Iran; B. decoloratus: Ethiopia, Zimbabwe, Tanzania, South Africa and Zambia; $R$. appendiculatus: Tanzania, Zambia, Uganda and Kenya; $R$. evertsi evertsi: Tanzania, South Africa and Ethiopia; R. pulchellus: Ethiopia; Rhipicephalus ssp.: Ghana) 
was most effective for killing resistant tick in vitro and in vivo conditions.

\section{Rotation of acaricides}

Rotation refers to the alternation of the use over time of two or more active ingredients with differing modes of action and no potential for cross-resistance (Rodriguez-Vivas et al. 2014b). Thullner et al. (2007) evaluated an acaricide rotation strategy for managing resistance in $R$. microplus under laboratory and field conditions in Costa Rica. The strain that they studied exhibited resistance to deltamethrin and a very low resistance to Ops, and it was kept under selection pressure for 9 to 11 generations by using deltamethrin or coumaphos, either exclusively or in rotation. In the sub-strains selected continuously with coumaphos or coumaphos and deltamethrin in rotation, no significant increase in resistance to deltamethrin was observed. In Australia, Jonsson et al. (2010b) treated calves with $R$. microplus amitraz resistance, with amitraz alone, spinosad alone or a rotation between spinosad and amitraz every 2 months over 4 years. The treatments with spinosad and spinosad in rotation with amitraz treatments resulted in the loss of amitraz resistance and a return to full or almost full susceptibility to amitraz. The loss of resistance to amitraz suggested that rotation of amitraz with other acaricides might prolong the useful life of the product.

Besides these laboratory and field studies to demonstrate that rotations show some promise for the management of acaricide resistance, the results can be expected to vary depending on the fitness and mode of inheritance of a particular form of resistance (George et al. 2004). Amitraz is an example of an acaricide that might possibly be used effectively in a rotation program because there is some evidence of loss of resistance to amitraz in populations of ticks on farms where cattle were treated with other alternatives and the mode of inheritance appears to be recessive. Conversely, in R. microplus resistant to SP and OP, reversion to susceptibility is difficult because it has been demonstrated that resistance persist to OP and SP for several years (Rodriguez-Vivas et al. 2005, 2011). Additionally, Aguilar-Tipacamu et al. (2008) demonstrated that the main mode of inheritance of SPs in $R$. microplus is by a partially dominant trait.

\section{Correct application of acaricide and macrocyclic lactones}

Short time intervals between successive acaridide treatments are associated with an increase in the proportion of a population that is resistant to an acaricide. In New Caledonia, Bianchi et al. (2003) reported that farmers are accustomed to controlling ticks every month or whenever they observe a substantial tick infestation. When the ticks become resistant, the first reaction of the farmers is to decrease the interval between treatments. Frequent applications of acaricides and its association with acaricide (Sutherst 1979; Jonsson et al. 2000; Rodriguez-Vivas et al. 2006a) and ML resistance in R. microplus (Fernandez-Salas et al. 2012a) have been demonstrated worldwide.

In countries with well-developed systems of agricultural pesticide regulation, there is a little chance that the manipulation of acaricide concentration will ever be an option as a method to delay the emergence of resistance, because legislation generally prescribes their use only at the acaricide concentrations specified on their label (Guerrero et al. 2014). However, in some developing countries, acaricide concentrations are manipulated by farmers from time to time (Higa et al. 2016).

Dosage determination of injectable formulations of ML to control ticks and nematodes on cattle is based on the body weight of individual animal. However, on cattle ranches with low income, cattle farmers calculate the weight of animals by visual appraisal. This practice could obviously enable misuse of drugs which would possibly lead to treatment failures as a result of inappropriate dosing by underestimation of the live weight. Despite this well-known statement in relation to nematodes, visual estimation of body weight to treat cattle with ivermectin has not been associated with ivermectin resistance in R. microplus (Fernandez-Salas et al., 2012a). Further studies are needed to verify whether variation in dose of ML has any effect on the frequency of resistant alleles under laboratory and field conditions.

The method of acaricide application is significantly related to tick resistance. The hand spray does not sufficient wet cattle, and this can be induced by insufficient pump pressure or the obstruction of nozzles. Bianchi et al. (2003) mentioned that this defect could select resistant strains; however, Jonsson et al. (2000) found in Australia that the use of a spray race to apply acaricides was associated with higher probabilities of Lamington (resistant to flumethrin) and Parkhurst resistance (resistant to all synthetic pyrethroids), while the use of a hand spray reduced the likelihood of Ulam resistance (resistant to amitraz). The hand spray method leaves many ticks completely unexposed to acaricides, and the relative fitness of susceptible homozygotes would be increased, delaying the development of resistance. Further studies are needed to clarify this statement.

\section{Non-acaricidal control of ticks}

\section{Manual removal}

The manual removal of ticks is mainly practised in developing countries and is only able to be applied on small farms where the number of tick-infested cattle is low. Muhammad et al. (2008) noted that care is required when removing ticks from animals because ticks can also transmit deadly pathogens to humans (i.e. Crimean-Congo hemorrhagic fever virus, 
usually associated with ticks of the genus Hyalomma). WingChing-Jones (2015) studied the impact of manual removal of $R$. microplus ticks on tick densities on Jersey dairy cows over 4 years in Costa Rica. During the morning milking, twice a week, ticks with a size between 5 and $10 \mathrm{~mm}$ long were counted and removed. The technique reduced the tick population by $21 \%$; however, its efficacy was conditional on the number of animals in the herd and personnel availability.

\section{Host resistance}

Host resistance of cattle to ticks is associated with a reduced number of ticks feeding to engorgement, reduced egg production and reduced egg viability (Wikel 1996). Differences in the ability of cattle to become resistant to ticks, whether Bos indicus or Bos taurus or within the B. taurus breed, have long been recognized, as has the fact that the ability to acquire resistance is heritable (Utech et al. 1978). In Bos indicus-cross cattle for example, heritability estimate for burden of R. microplus is moderate $\left(h^{2}=0.34\right.$, Mackinnon et al. 1991). It has also been shown that Bos indicus or their crossbreeds are more able to survive babesiosis (a tick-borne disease transmitted by B. bovis and B. bigemina) than B. taurus animals (Bock et al. 1997). The mechanisms of resistance to infestation with ticks have been reviewed elsewhere (Jonsson et al. 2014). The potential reduction in acaricide requirement arising from concerted selection and breeding of cattle for increased host resistance is very substantial. Indicine cattle carry between 10 and $20 \%$ of the number of ticks that taurine cattle would carry given the same level of larval tick challenge (Jonsson et al. 2014). Whereas the most rapid gains in host resistance can be made by replacing taurine cattle with indicine breeds or crossbreeds, molecular genetic markers of host resistance have been identified and with further development hold promise of more rapid selection for host resistance within breeds (Porto Neto et al. 2011).

\section{Release of sterile male hybrids}

It has been shown that $R$. annulatus $\times R$. microplus matings produce fertile females and sterile males (Osburn and Knipling, 1982). Backcrossing of the fertile female progeny also produces sterile males and fertile females through three to six generations. To be successful, release of hybrid ticks must be into small populations, for example where there is a new outbreak or where there is already a high degree of control by other means (Hillburn et al. 1991). Problems with this method of control include the cost of production of hybrids, the effects of moderate infestations of hybrids over the period of eradication and the risk of an extended range of hybrid or R. annulatus ticks (Jonsson 1997).

\section{Enviromental and animal management}

Management of refugia (parasitic populations that have not been exposed to a particular drug and hence still contains a large proportion of susceptible organisms) by pasture rotation and strategic administration of anthelmintics, treating only the most heavily parasitized animals, has been used in horses and ruminants to delay progression of helminth resistance (Rodriguez-Vivas et al. 2014b). This type of management can be applied for tick control. The following is a brief overview of the major enviromental and animal management practices that contribute to control ticks.

\section{Plant species that are unfavourable to ticks}

Some plants have been shown to act as attractants for ticks; Wilson et al. (1989) demonstrated that Stylosanthes scabra (a tropical legume) can trap between 12 and 27\% larvae in the sticky exudate of glandular trichomes on stems and leaves. However, the effectiveness for tick control is limited by the proportion of this plant in pastures and the physiological state of the plant. Additionally, the African shrub Acalypha fruticosa is reported to attract larvae of $R$. appendiculatus, which lie quiescent on the underside of the leaf plant (Hassan et al. 1994).

\section{Grazing management}

Pasture management in which grazing patterns are used to interrupt the life cycle of ticks can be use in an integrated tick control (Stachurski and Adakal 2010; Abbas et al. 2014). Pasture spelling was implemented to starve larval ticks by rotating cattle into 'clean' paddocks at specified intervals. In Australia, spelling periods of 3-4 months were considered necessary, but such long periods sometimes have adverse effects on pasture quality. Pasture spelling was used effectively in certain situations but had limited appeal to producers because of managerial difficulties, the cost of fencing and pasture irrigation facilities and the possible adverse effect on pasture quality (Elder et al. 1982).

\section{Pasture burning}

Burning pasture is a widely used practice for controlling ticks in many countries like South Africa, Zambia, Australia, the USA and Mexico (Abbas et al. 2014). Fire directly affects ticks due to the exposure of larvae, adult females and eggs to high temperatures. Indirectly, it has an effect by the destruction of the vegetation layer that serves as protection to the ticks (Rodriguez-Vivas et al. 2014b). 


\section{Animal nutrition}

Energy and protein are important in mediating acquired resistance to ticks (Wikel 2013). In a field study carried out in eastern Queensland, Australia, feeding on poor-quality pastures resulted in a significant loss of resistance in the Bos taurus and B. indicus $\times$ B. taurus steers and heifers to $R$. microplus. Sutherst et al. (1983) mentioned that animals grazing native pastures, with poor-quality feed in lateautumn and winter, suffered substantial losses of resistance of ticks.

\section{Plant extracts and essential oils to control ticks}

Many species of plants have been evaluated for acaricidal activity, with the species studied mainly being members of the families Poaceae, Fabaceae, Lamiaceae, Verbenaceae, Piperaceae and Asteraceae (Borges et al. 2011; Muyobela et al. 2016; Dantas et al. 2016). Some studies have identified secondary metabolites (terpenes, stilbenes, coumarins, alcohols, acids, sulfurated compounds and aldehydes) of essential oils and plant extracts, associated with acaricidal effects against the genera Amblyomma, Rhipicephalus, Hyalomma, Dermacentor, Argas and Ixodes (Pamo et al. 2005; Cetin et al. 2010). In this section, only few examples of plant extracts and essential oils with acaricide property will be described. For more comprehensive article, we recommend Borges et al. (2011) and Rosado-Aguilar et al. (2017).

Srivastava et al. (2008) evaluated the ethanolic crude extract of Azadirachta indica, Mangifera indica, Prunus persica, Curcuma longa and Psidium guajava. Azadirachta indica seed extract was more effective (80\%) than $P$. persica seed $(70 \%)$ and $A$. indica leaf (30\%). The extracts prepared from $A$. indica bark, $P$. persica leaf and $M$. indica bark had no effect on the adults of $R$. microplus, while only $10 \%$ of adults died when treated with the extract of $C$. longa. FernandezSalas et al. (2011) evaluated the acaricidal activity of acetone-water extracts from the fresh leaves from four tanninrich plants (Acacia pennatula, Leucaena leucocephala, Piscidia piscipula and Lysiloma latisiliquum) against the larvae and adult ticks of $R$. microplus. The following mortality rates were obtained: $54.8 \%$ for A. pennatula, $66.7 \%$ for L. leucocephala, $88.1 \%$ for P. piscipula and $56.0 \%$ for L. latisiliquum. However, none of the evaluated plants showed acaricidal activity against adult ticks. Sardá-Ribeiro et al. (2008) evaluated the hexane extract from the aerial parts of Calea serrata to control larvae and adults of $R$. sanguineus and $R$. microplus, showing $100 \%$ mortality in the larvae of both tick species and a reduction in oviposition of $11-14 \%$. In two studies conducted by Broglio-Micheletti et al. (2009, 2010), extracts and commercial products using $A$. indica were evaluated. Ethanolic extracts from leaves and hexanic extracts from seeds had efficacy of 2.3 and 38.4, respectively, on
R. microplus female reproduction (Broglio-Micheletti et al. 2009). Efficiency of commercial formulations of alcoholic and hexanic extracts from seeds was from 17 to $73 \%$ (Broglio-Micheletti et al. 2010). In another study, the essential oil of Cymbopogon winterianus was avaluated against larvae and engorged females of $R$. microplus. Total inhibition of eclosion was observed at a concentration of 7.1 and $100 \%$ of larval mortality at concentrations between 5.5 and $7.1 \%$. The principal components of the essential oil, i.e. geraniol, citronellal and citronellol, were tested against engorged females, and the best results were observed for geraniol and citronella. Rosado-Aguilar et al. (2010) studied the acaricidal activity of crude extracts and fractions from stems and leaves of Petiveria alliacea against larvae and engorged females of $R$. microplus. Methanolic extracts of leaves and stems of $P$. alliacea showed $100 \%$ mortality of larvae. The methanolic extracts of stem and leaves on engorged females showed 86 and $26 \%$ of mortality, respectively, egg laying inhibition of 91 and $40 \%$, respectively, and hatchability inhibition of 17 and 26\%, respectively. Purification of the active stem methanolic extract showed six main compounds: benzyl disulfide, benzyl trisulphide, cis-stilbene, methyl esters of hexadecanoic acid, octadecadienoic acid and octadecenoic acid. To validate the acaricidal activity of these compounds, Arceo-Medina et al. (2016) evaluated the six commercially available compounds individually and in 57 combinations. The mixtures based on the benzyl trisulphide + benzyl disulfide pairing produced a synergistic effect against acaricide-resistant $R$. microplus larvae and engorged females and were therefore the most promising combination for controlling this ectoparasite. Recently, Avinash et al. (2017) studied the in vitro acaricidal activity of neem-coated silver nanoparticles on deltamethrin resistance $R$. microplus. These nanoparticles produced $93 \%$ mortality at $50 \mathrm{ppm}$ and efficacious inhibition of oviposition and reproductive index of engorged females.

Although several plant extracts have been tested against $R$. microplus in laboratory conditions, only a few of them have also been evaluated on $R$. microplus-infested animals in order to validate the results obtained (Borges et al. 2011). One expected advantage from the use of any effective botanical compounds would be slow development of resistance because there is usually a mixture of different active componds with different mechanisms of action.

\section{Vaccination}

Immunization against ticks at present seems appealing due to its potential for the prevention of drug-resistant ticks and reduction of environmental damage (Guerrero et al. 2012). Tick antigens are usually classified as either exposed or concealed antigens. Exposed antigens are those that naturally come into contact with the host immune system during tick feeding (i.e. antigens from the salivary gland and its secretions and 
cuticle), and animals are continually exposed to this class of antigen during infestation. Conversely, concealed antigens (including some antigens from gut epithelium) are not exposed to the host immune system during tick feeding, and therefore, repeated vaccinations are required to maintain high antibody titers (Manjunathachar et al. 2014).

Willadsen et al. (1989) first identified the Bm86 antigenconcealed antigen from the midgut of engorged female $R$. microplus tick and demonstrated its efficacy as a vaccine in both its native and recombinant forms. The authors subsequently developed an expression system for Bm86, and it was commercialized in Australia as TickGARD® (Willadsen et al. 1995). Bm86-based vaccines cause leakage of gut content into the haemocoele of ticks, slightly reducing the number of females engorging, their mean weight and fecundity and reducing larval production. Another commercial vaccine containing a recombinant Bm86 antigen (Gavac ${ }^{\circledR}$ ) was released in Mexico, Argentina and Colombia in 1997 (Canales et al. 1997). Controlled pen and field trials in Mexico provided evidence of the effect of recombinant Bm86 vaccination for the control of $R$. microplus and $R$. annulatus infestations (de la Fuente et al. 2007).

The mechanism of Bm86-based vaccine against tick infestation is based on polyclonal antibody response against the concealed antigen. Regional variation in the sequence of Bm86 has been proposed to influence the efficacy of Bm86based recombinant vaccines (Manjunathachar et al. 2014). Studies in Argentina revealed polymorphisms in the Bm86 gene that affected expression of the gene and resulted in the production of a soluble rather than a membrane-bound protein in ticks that were apparently resistant to vaccination with the original Bm86 (Garcia-Garcia et al. 2000). Field trials of the TickGARD ${ }^{\circledR}$ vaccine in some areas of Brazil showed low levels of efficacy (Pereira et al. 2008). Gavac $®$ remains commercially available in some Latin American countries, but TickGARD ${ }^{\circledR}$ is no longer commercially available in Australia (Schetters et al. 2016).

Research towards the development of more effective vaccines has received considerable support in recent years, and there are many promising candidates as well as studies to improve the efficacy and delivery of the existing antigen. A detailed overview and evaluation of all publicly reported candidates is beyond the scope of this review, and the subject is covered elsewhere (e.g. Schetters et al. 2016).

\section{Biological control}

Biological control is defined broadly as the use of live organisms to reduce the populations of pest/pathogenic organisms. A distinction is often made between biopesticides and biological control agents. Biopesticides are live organisms or products thereof, which must be applied directly and whenever needed to the pest to control it. Biopesticides do not survive, establish populations and proliferate in the environment and are therefore not expected to have a persistent effect arising from their survival. In contrast, biological control agents are expected to establish in the environment and to have an ongoing effect on the pest species. They can be considered as depressing the equilibrium population of the pest in their environment. Examples of biological control agents include predators, pathogens, parasites and resistant plants. Research has been conducted on nematodes (Heterorhabditis spp. and Steinernema spp.), ants (Solenopsis germinata, S. saevissima and Ectatomma cuadridens) and many bird species (Samish et al. 2004; Ojeda-Chi et al. 2011). Entomopathogenic fungi and Bacillus thuringiensis and its products are generally considered to be biopesticides. General predators can sometimes affect the size of a tick population in nature, but manipulating their populations to reduce tick numbers would require large increases in the predator population, which could also cause large changes in populations of non-target species in natural areas (Samish et al. 2004).

The entomopathogenic fungi that have been evaluated for the control of $R$. microplus are mainly Beauveria bassiana, Lecanicillium lecanii and Metarhizium anisopliae, which have shown potential efficacy in the control of various tick developmental stages (egg, larva, nymph, adult) (Ojeda-Chi et al. 2011). Laboratory and field evaluations of $M$. anisopliae for the control of R. microplus have been documented worldwide (Samish et al. 2004). Frazzon et al. (2000) studied 12 strains of M. anisopliae and found four strains that killed $50 \%$ of engorged females after a single fungal immersion. During a subsequent immersion $\left(1 \times 10^{7}\right.$ conidia/ml $)$, nine strains killed $100 \%$ of ticks. Fernandez et al. (2005) found a highly effective $M$. anisopliae strain that killed $100 \%$ of engorged females, both resistant and susceptible to acaricides, with a $1 \times 10^{8}$ conidia $/ \mathrm{ml}$ concentration. Gindin et al. (2001) also found a M. anisopliae strain that killed 80-100\% engorged females of $R$. annulatus. In the Mexican tropics, Ojeda-Chi et al. (2010) tested the effect of two strains of $M$. anisopliae to control $R$. microplus under laboratory and field conditions (larvae on vegetation). The efficacies in laboratory conditions at $1 \times 10^{8}$ conidia/ml concentration for larvae and adult stages were 45-100 and $100 \%$, respectively. The efficacy of $M$. anisopliae to control $R$. microplus larvae on vegetation varied from 68 to $100 \%$. General efficacy of M. anisopliae to control $R$. microplus in in vitro and in vivo (on animals and on vegetation) conditions are $50-100$ and $36-90 \%$, respectively (Ojeda-Chi et al. 2011). The efficacy of M. anisopliae varies depending on the strain and conidial concentration (Fernandes et al. 2004; Samish et al. 2004). Kirkland et al. (2004) mentioned that virulence depends on the ability of $M$. anisopliae to penetrate directly through the tick cuticle using enzymatic and physical mechanisms. 
Despite the promising laboratory results with fungal biopesticides for the control of ticks, in vivo studies have not repeatably yielded promising results.

\section{Integrated tick management}

Integrated tick management (ITM) consists of the systematic combination of two or more technologies to control pest populations which adversely affect the host species, while maintaining adequate levels of animal production. The aim of this management is "to achieve pest control in a more sustainable, environmentally compatible and cost-effective manner than is achievable with a single, stand alone technology" (Willadsen 2006). In the development of approaches which allow effective management of tick populations, which minimize nontarget effects and preserve the availability of the existing acaricides, it is essential to develop more fully the use of ITM. In such approaches, combinations of management tools may be deployed as and when necessary, with acaricide available as just one component, to be used in appropriate circumstances (Guerrero et al. 2014). A wide range of new tools are becoming available to assist in this goal. These include molecular techniques, which can provide powerful new insights into diagnosis, spatial distribution of ticks, acaricide resistance of ticks, simulation modelling, satellite imagery, anti-tick vaccines and biological control (Jonsson 2004; Estrada-Peña and Venzal 2006; Alonso-Díaz et al. 2007; de la Fuente et al. 2007; Jonsson and Hope 2007; Rodriguez-Vivas et al. 2007; Ojeda-Chi et al. 2010). However, there is little evidence that these tools are being applied to any extent in the field.

In Mexico, the anti-tick vaccine (Gavac ${ }^{\circledR}$ ) and acaricide treatments have been used together to control $R$. microplus ticks. Redondo et al. (1999), using an integrated system employing vaccination with amitraz treatments and Gavac®, under field conditions achieved nearly $100 \%$ control of R. microplus populations resistant to OPs and SPs. This method effectively controls tick infestations while reducing the number of chemical acaricide treatments and consequently the rise of $R$. microplus populations resistant to acaricides. Furthermore, in a farm using this ITM for 10 years, a substantial reduction of acaricide treatments was achieved (from 24 to 7-8 per year) with consequent reduction in tick infestation from 100 to 20 adult ticks per animal (de la Fuente et al. 2007).

Bahiense et al. (2006) evaluated the combined use of the entomopathogenic fungus $M$. anisopliae and deltamethrin against $R$. microplus larvae that were resistant to SP. High mortality rates were observed when deltamethrin was associated with the entomopathogen. The potential utilization of associated chemical acaricides with biological agents could stimulate the use and consolidation of biological control for animal parasites among farmers and practitioners (Webster et al. 2015).
The use of tick-resistant cattle breeds (B. indicus and their crosses), host management (i.e. lowering the stocking rate), selection application of acaricide during annual season when they will be most effective and pasture rotation and spelling can be useful components of an ITM (Rodriguez-Vivas et al. 2014b).

There are many studies demonstrating that the integrated management of parasites is the best option to increase the productive capacity of animals; however, studies are mainly based on the control of one type of parasite (i.e. ticks) by the use of several control approaches. Because internal (i.e. gastrointestinal nematodes) and external parasites (i.e. ticks, flies, lice) of cattle occur in natural conditions simultaneously, it is necessary to control different types of parasites. The main challenge that exists worldwide is the efficient use of an integrated program of parasites in livestock (unless it controls ticks, gastrointestinal nematodes and hematophagous flies) through the implementation of coordinated strategies of chemical and nonchemical control (Rodriguez-Vivas et al. 2014b).

\section{Conclusions}

The control of Rhipicephalus ticks, especially R. microplus, is achieved mainly by chemical acaricides and ML. However, there is measureable resistance to most of the compounds that are commercially available, and this can be expected to increase. There is a need to develop and validate the efficacy of strategies for tick control that will delay the emergence of resistance. Selection pressure can be reduced by including non-acaricide-based controls (i.e. integrated tick management) and by using targeted treatments to maximize refugia. Mixtures of compounds will increasingly be required in response to increased prevalence of acaricide resistance. Biosecurity should be given high priority to reduce the dispersal of resistance-conferring variants. The value of rotation of acaricides should be investigated for a range of compounds under field conditions.

Open Access This article is distributed under the terms of the Creative Commons Attribution 4.0 International License (http:// creativecommons.org/licenses/by/4.0/), which permits unrestricted use, distribution, and reproduction in any medium, provided you give appropriate credit to the original author(s) and the source, provide a link to the Creative Commons license, and indicate if changes were made.

\section{References}

Abbas RZ, Zaman MA, Colwell DD, Gilleard J, Iqbal Z (2014) Acaricide resistance in cattle ticks and approaches to its management: the state of play. Vet Parasitol 203:6-20 
Adehan SB, Biguezoton A, Adakal H, Assogba MN, Zoungrana A, Gbaguidi M, Tonouhewa A, Kandé S, Achi L, Kagone H, Adehan R, Mensah GA, De Deken R, Madder M, Farougou S (2016) Acaricide resistance of Rhipicephalus microplus ticks in Benin. Afr J Agric Res 11(14):1199-1208

Aguilar-Tipacamu G, Miller RJ, Hernández-Ortiz R, Rodriguez-Vivas RI, Vásquez-Peláez C, García-Vázquez Z, Olvera VF, Rosario-Cruz R (2008) Inheritance of pyrethroid resistance and a sodium channel gene mutation in the cattle tick Boophilus microplus. Parasitol Res 103:633-639

Aguilar-Tipacamu G, Rodriguez-Vivas RI (2003) Effect of moxidectin against natural infestation of the cattle tick Boophilus microplus (Acari: Ixodidae) in the Mexican tropics. Vet Parasitol 111:211-216

Ahmed MAI, Matsumura F (2012) Synergistic actions of formamidine insecticides on the activity of pyrethroids and neonicotinoids against Aedes aegypti (Diptera: Culicidae). J Med Entomol 49(6):1405-1410

Alonso-Díaz MA, García L, Galindo-Velasco E, Lezama-Gutiérrez R, Angel-Sahagún C, Rodríguez-Vivas RI, Fragoso-Sánchez H (2007) Evaluation of Metarhizium anisopliae (Hyphomycetes) for the control of Boophilus microplus (Acari: Ixodidae) on naturally infested cattle in the Mexican tropics. Vet Parasitol 147:336-340

Alvarez V, Hernandez V (2010) Diagnóstico de resistencia a organofosforados, piretroides sintéticos, amidinas e ivermectinas en la garrapata Rhipicephalus microplus en fincas de productores de leche de Costa Rica. Revista FAVE - Cien Vet 9(2):47-56

Andreotti R, Guerrero FD, Soares MA, Barros JC, Miller RJ, de Léon AP (2011) Acaricide resistance of Rhipicephalus (Boophilus) microplus in state of Mato Grosso do Sul, Brazil. Rev Bras Parasitol Vet 20(2): $127-133$

Araque A, Ujueta S, Bonilla R, Gómez D, Rivera J (2014) Resistencia a acaricidas en Rhipicephalus (Boophilus) microplus de algunas explotaciones ganaderas de Colombia. Rev UDCA 17(1):161-170

Arceo-Medina GN, Rosado-Aguilar JA, Rodriguez-Vivas RI, BorgesArgaez R (2016) Synergistic and antagonistic action of fatty acids, sulphides and stilbene against acaricide-resistant Rhipicephalus microplus ticks. Vet Parasitol 228:121-125

Arieta-Román RJ, Rodríguez-Vivas RI, Rosado-Aguilar JA, RamírezCruz GT, Basto-Estrella G (2010) Persistencia de la eficacia de dos lactonas macrocíclicas contra infestaciones naturales de Rhipicephalus (Boophilus) microplus en bovinos del trópico mexicano. Rev Mex Cienc Pecu 1(1):59-67

Avinash B, Venu R, Alpha Raj M, Srinivasa Rao K, Srilatha C, Prasad TN (2017) In vitro evaluation of acaricidal activity of novel green silver nanoparticles against deltamethrin resistance Rhipicephalus (Boophilus) microplus. Vet Parasitol 237:130-136

Bahiense TC, Fernandes EKK, Bittencourt VREP (2006) Compatibility of the fungus Metarhizium anisopliae and deltamethrin to control a resistant strain of Boophilus microplus tick. Vet Parasitol 141:319-324

Baker JAF, Shaw RD (1965) Toxaphene and lindane resistance in Rhipicephalus appendiculatus, the brown ear tick of equatorial and Southern Africa. J South African Vet Assoc 36(3):321-330

Baron S, van der Merwe NA, Madder M, Maritz-Olivier C (2015) SNP analysis infers that recombination is involved in the evolution of amitraz resistance in Rhipicephalus microplus. PLoS One 10(7): e0131341

Barré N, Li AY, Miller RJ, Gaia H, Delathiere JM, Davey RB, George JE (2008) In vitro and in vivo evaluation of deltamethrin and amitraz mixtures for the control of Rhipicephalus (Boophilus) microplus (Acari, Ixodidae) in New Caledonia. Vet Parasitol 155:110-119

Baxter GD, Barker SC (1999) Isolation of a cDNA for an octopaminelike, G-protein coupled receptor from the cattle tick, Boophilus microplus. Insect Biochem Molec 29:461-467

Baxter GD, Barker SC (1998) Acethylcholinesterase cDNA of the cattle tick Boophilus role in organophosphates resistance. Insect Biochem Molec 28:581-589
Benavides E, Rodríguez JL, Romero A (2000) Isolation and partial characterization of the Montecitos strain of Boophilus microplus (Canestrini, 1877) multiresistant to different acaricides. Ann N Y Acad Sci 916:668-671

Beugnet F, Chardonnet L (1995) Tick resistance in New Caledonia. Vet Parasitol 56:325-338

Beugnet F, Franc M (2012) Insecticide and acaricide molecules and/or combinations to prevent pet infestation by ectoparasites. Trends Parasitol 28(7):267-279

Bianchi MW, Barré N, Messa S (2003) Factors related to cattle infestation level and resistance to acaricides in Boophilus microplus tick populations in New Caledonia. Vet Parasitol 112(1-2):75-89

Bock RE, de Vos AJ, Kingston TG, McLellan DJ (1997) Effect of breed of cattle on innate resistance to infection with Babesia bovis, Babesia bigemina and Anaplasma marginale. Aust Vet J 75:337-340

Borges LMF, Sousa LAD, Barbosa CS (2011) Perspectives for the use of plant extracts to control the cattle tick Rhipicephalus (Boophilus) microplus. Rev Bras Parasitol Vet 20(2):89-96

Bourguet D, Genissel A, Raymond M (2000) Insecticide resistance and dominance levels. J Econ Entomol 93:1588-1595

Broglio-Micheletti SMF, Valente ECN, de Souza LA, Dias NS, de Araújo AMN (2009) Extratos de plantas no controle de Rhipicephalus (Boophilus) microplus (Canestrini, 1887) (Acari: Ixodidae) em laboratório. Rev Bras Parasitol Vet 18(4):44-48

Broglio-Micheletti SMF, Dias NS, Valente ECN, de Souza LA, Lopes DOP, dos Santos JM (2010) Ação de extrato e óleo de nim no controle de Rhipicephalus (Boophilus) microplus (Canestrini, 1887) (Acari: Ixodidae) em laboratório. Rev Bras Parasitol Vet 19(1):46-50

Brun LO, Wilson JT, Daynes P (1983) Ethion resistance in the cattle tick (Boophilus microplus) in New Caledonia. Trop Pest Manag 29(1): 16-22

Busch JD, Stone NE, Nottingham R, Araya-Anchetta A, Lewis J, Hochhalter C, Giles JR, Gruendike J, Freeman J, Buckmeier G, Bodine D, Duhaime R, Miller RJ, Davey RB, Olafson PU, Scoles GA, Wagner DM (2014) Widespread movement of invasive cattle fever ticks (Rhipicephalus microplus) in southern Texas leads to shared local infestations on cattle and deer. Parasites Vect 7:188

Cabrera-Jimenez D, Rodriguez-Vivas RI, Rosado-Aguilar JA (2008) Evaluación de la resistencia a la cipermetina en cepas de campo de Boophilus microplus obtenidas de ranchos bovinos del estado de Yucatán, México. Rev Mex Cien Pec 1:59-67

Canales M, Enriquez A, Ramos E, Cabrera D, Dandie H, Soto A, Falcón V, Rodríguez M, de la Fuente J (1997) Large-scale production in Pichia pastoris of the recombinant vaccine Gavac against cattle tick. Vaccine 15:414-422

Castro-Janer E, Klafke GM, Capurro ML, Schumaker TT (2015) Crossresistance between fipronil and lindane in Rhipicephalus (Boophilus) microplus. Vet Parasitol 210(1-2):77-83

Castro-Janer E, Martins JR, Mendes MC, Namindome A, Klafke GM, TTS S (2010) Diagnoses of fipronil resistance in Brazilian cattle ticks Rhipicephalus (Boophilus) microplus using in vitro larval bioassays. Vet Parasitol 173(3-4):300-306

Castro-Janer E, Rifran L, González P, Niell C, Piaggio J, Gil A, TTS S (2011) Determination of the susceptibility of Rhipicephalus (Boophilus) microplus (Acari: Ixodidae) to ivermectin and fipronil by larval immersion test (LIT) in Uruguay. Vet Parasitol 178:148-155

Castro-Janer E, Rifran L, González P, Piaggio J, Gil A, Schumaker TT (2009) Rhipicephalus (Boophilus) microplus (Acari: Ixodidae) resistance to fipronil in Uruguay evaluated by in vitro bioassays. Vet Parasitol 169(1-2):172-177

Cetin H, Cilek JE, Oz E, Aydin L, Deveci O, Yanikoglu A (2010) Acaricidal activity of Satureja thymbra L. essential oil and its major components, carvacrol and $\gamma$-terpinene against adult Hyalomma marginatum (Acari: Ixodidae). Vet Parasitol 170:287-290 
Chaudhuri RP, Naithani RC (1964) Resistance to BHC in the cattle tick Boophillus microplus (Can.) in India. Bull Entomol Soc Am 55(3): 405-410

Chen AC, He H, Davey RB (2007) Mutations in a putative octopamine receptor gene in amitraz-resistant cattle ticks. Vet Parasitol 148:379-383

Coetzee BB, Stanford GD, Davis DAT (1987) Resistance by the blue tick (Boophilus decoloratus) to a range of ixodicides. Onderstepoort $\mathrm{J}$ Vet Res 54:79-82

Corley SW, Jonsson NN, Piper EK, Cutullè C, Stear MJ, Seddon JM (2013) Mutation in the Rm $\beta$ AOR gene is associated with amitraz resistance in the cattle tick Rhipicephalus microplus. Proc Natl Acad Sci U S A 110(42):16772-16777

Corley SW, Piper EK, Jonsson NN (2012) Generation of full-length cDNAs for eight putative GPCnR from the cattle tick, $R$. microplus using a targeted degenerate PCR and sequencing strategy. PLoS One 7(3):e32480

Coronado A (1999) Control quimico de Boophilus microplus en Venezuela. Situación actual In: Garcia VZ, Fragoso SH (Eds.) IV Seminario Internacional de Parasitologia Animal. Control de la resistencia en garrapatas y moscas de importancia veterinaria y enfermedades que trasmiten, CONASAG-INIFAP-INFARVETIICA-AMPAVE-FILASA, 20-22 de octubre de 1999, Puerto Vallarta, Jalisco, México, pp. 51-56

Coustau C, Chevillon C, ffrench-Constant R (2000) Resistance to xenobiotics and parasites, can we count the cost? Trends Ecol Evol 15: 378-383

Cuore U, Solari MA (2014) Poblaciones multirresistentes de garrapatas Rhipicephalus (Boophilus) microplus en Uruguay. Vet (Montevideo) 50(193):1-13

Cutullé C, Lovis L, D’Agostino BI, Balbiani GG, Morici G, Citroni D, Reggi J, Caracostantogolo JL (2013) In vitro diagnosis of the first case of amitraz resistance in Rhipicephalus microplus in Santo Tomé (Corrientes), Argentina. Vet Parasitol 192(1-3):296-300

Dantas AC, Araujo A, Marques AG, Branco A, Sangioni LA, Guedes JR, Horta MC (2016) Acaricidal activity of Amburana cearensis on the cattle tick Rhipicephalus (Boophilus) microplus. Cienc Rural 46: 536-541

Davey RB, George JE (1998) In vitro and in vivo evaluation of a strain of Boophilus microplus (Acari: Ixodidae) selected for resistance to permethrin. J Med Entomol 35:1013-1019

Davey RB, George JE (2002) Efficacy of macrocyclic lactone endectocides against Boophilus microplus (Acari: Ixodidae) infested cattle using different pour-on application treatment regimes. J Med Entomol 39:763-769

Davey RB, George JE, Miller RJ (2003) Efficacy of various concentrations of coumaphos to control adult, nymphal, and larval stages of an organophosphate-resistant strain of Boophilus microplus on infested cattle. Am J Vet Res, 689 64(6):684

Davey RB, George JE, Miller RJ (2004) Control of an organophosphateresistant strain of Boophilus microplus (Acari: Ixodidae) infested on cattle after a series of dips in coumaphos applied at different treatment intervals. J Med Entomol 41(3):524-528

Davey RB, George JE, Snyder DE (2001) Efficacy of a single wholebody spray treatment of spinosad, against Boophilus microplus (Acari: Ixodidae) on cattle. Vet Parasitol 99(1):41-52

Davey RB, George JR, Miller RJ (2006) Comparison of the reproductive biology between acaricide-resistant and acaricide-susceptible Rhipicephalus (Boophilus) microplus (Acari: Ixodidae). Vet Parasitol 139:211-220

Davey RB, Thomas DB, Pound JM, Lohmeyer KH, Miller RJ (2013) Efficacy of an organophosphate mixture against an organophosphate-resistant strain of Rhipicephalus (Boophilus) microplus (Acari: Ixodidae). J Entomol Sci 48(4):306-316

de la Fuente J, Almazan C, Canales M, Perez de la Lastra JM, Kocan KM, Willadsen P (2007) A ten-year review of commercial vaccine performance for control of tick infestations on cattle. Ani Hlth Res Rev 8(1):23-28

Dermauw W, Van Leeuwen T (2014) The ABC gene family in arthropods: comparative genomics and role in insecticide transport and resistance. Insect Biochem Mol Biol 45:89-110

Diaz RE, Vallejo G (2013) Identificación de un polimorfismo del gen Est9 relacionado con resistencia a piretroides en Rhipicephalus (Boophilus) microplus. Rev MVZ Córdoba 18(Suppl 1):3708-3714

Ducornez S, Barre N, Miller R, De Garine-Wichatitsky M (2005) Diagnosis of amitraz resistance in Boophilus microplus in New Caledonia with the modified larval packet test. Vet Parasitol 130: 285-292

Elder JK, Knott SG, Kearnan JF (1982) A coordinated approach to control of the cattle tick (Boophilus microplus) in South East Queensland, Australia. Proceedings of the 3rd International Symposium on Veterinary Epidemiology and Economics, Available at: www.sciquest.org.nz

Enayati AA, Asgarian F, Sharif M, Boujhmehrani H, Amouei A, Vahedi N, Boudaghi B, Piazak N, Hemingway J (2009) Propetamphos resistance in Rhipicephalus bursa (Acari, Ixodidae). Vet Parasitol 162(1-2):135-141

Estrada-Peña A, Venzal JM (2006) High-resolution predictive mapping for Boophilus annulatus and B. microplus (Acari: Ixodidae) in Mexico and southern Texas. Vet Parasitol 142:350-358

FAO (1987) Food and Agriculture Organization of the United Nations. Control de las Garrapatas y de las Enfermedades que Transmiten: Manual Práctico de Campo FAO 1:5-20

FAO (2004) Food and Agriculture Organization of the United Nations. Guidelines Resistance Management Integrated Parasite Control Ruminants, Module 1:56

Fernandes EKK, Costa GL, Moreas AML (2004) Entomopathogenic potential of $M$. anisopliae isolated from engorged females and tested in eggs and larvae of B. microplus (Acari: Ixodidae). J Basic Microbiol 44:324-332

Fernandez M, Zhioua E, García Z (2005) Infectividad de Metarhizium anisopliae en contra de cepas de garrapatas Boophilus microplus sensibles y resistentes a los organofosforados. Téc Pec Méx 43(3): 433-440

Fernandez-Salas A, Alonso-Díaz MA, Acosta-Rodríguez R, JFJ T-A, Sandoval-Castro CA, Rodriguez-Vivas RI (2011) In vitro acaricidal effect of tannin-rich plants against the cattle tick Rhipicephalus (Boophilus) microplus (Acari: Ixodidae). Vet Parasitol 175:113-118

Fernandez-Salas A, Rodriguez-Vivas RI, Alonso-Díaz MA (2012b) First report of a Rhipicephalus microplus tick population multi-resistant to acaricides and ivermectin in the Mexican tropics. Vet Parasitol 183(3-4):338-342

Fernandez-Salas A, Rodriguez-Vivas RI, Alonso-Diaz MA (2012c) Resistance of Rhipicephalus microplus to amitraz and cypermethrin in tropical cattle farms in Veracruz, Mexico. J Parasitol 98(5):1010-1014

Fernandez-Salas A, Rodriguez-Vivas RI, Alonso-Diaz MA, BasurtoCamberos H (2012a) Ivermectin resistance status and factors associated in Rhipicephalus microplus (Acari: Ixodidae) populations from Veracruz, Mexico. Vet Parasitol 190:210-215

Feyera T, Admasu P, Wakayo BU, Megersa M (2015) In vitro and in vivo acaricidal efficacy study of amitraz and diazinon against some tick species infesting Camelus dromedarius around Jigjiga, Eastern Ethiopia. Afr J Pharm 9(34):850-855

ffrench-Constant RH, Roush RT (1990) Resistance detection and documentation, the relative roles of pesticidal and biochemical assays. In: Roush RT, Tabashnik BE (eds) Pesticide resistance in arthropods. Chapman and Hall, New York, pp 4-38

Fragoso SH, Ortiz EM, Soberanes CN, Santamaría VM, Ortiz NA (1995) Epidemiología de la resistencia a ixodicidas en garrapatas Boophilus microplus en la República Mexicana. In: III Seminario Internacional de Parasitología Animal. Resistencia y control en garrapatas y 
moscas de importancia veterinaria, Acapulco, Guerrero, México, 11-13 de octubre de 1995, pp. 45-57

Fragoso-Sanchez H, Garcia-Vazquez Z, Tapia-Perez G, Ortiz-Najera A, Rosario-Cruz R, Rodriguez-Vivas RI (2011) Response of Mexican Riphicephalus (Boophilus) microplus ticks to selection by amitraz and genetic analysis of attained resistance. J Entomol 8(3):1812-5670

Frazzon GAP, Vaz SI Jr, Masuda A, Schrank A, Vainstein HM (2000) In vitro assessment of Metarhizium anisopliae isolates to control the cattle tick Boophilus microplus. Vet Parasitol 94:117-125

Garcia-Garcia JC, Montero C, Redondo M, Vargas M, Canales M, Boue O, Rodríguez M, Joglar M, Machado H, González IL, Valdés M, Méndez L, de la Fuente J (2000) Control of tick resistant to immunization with Bm86 in cattle vaccinated with the recombinant antigen Bm95 isolated from the cattle tick, Boophilus microplus. Vaccine 8:2275-2287

Gaur RS, Sangwan AK, Sangwan N, Kumar S (2016) Acaricide resistance in Rhipicephalus (Boophilus) microplus and Hyalomma anatolicum collected from Haryana and Rajasthan states of India. Exp Appl Acarol 69:487

George JE, Pound JM, Davey RB (2004) Chemical control of ticks on cattle and the resistance of these parasites to acaricides. Parasitology 129(Suppl S1):S353-S366

Ghosh S, Kumar R, Nagar G, Kumar S, Sharma AK, Srivastava A, Kumar S, Kumar KA, Saravanan B (2015) Survey of acaricides resistance status of Rhipiciphalus (Boophilus) microplus collected from selected places of Bihar, an eastern state of India. Ticks Tick Borne Dis 6(5):668-675

Gindin G, Samish M, Alekeseev E, Glazer I (2001) The susceptibility of Boophilus annulatus (Ixodidae) ticks to entomopathogenic fungi biocontrol. Sci Technol 11:111-118

Gould F, Anderson A, Jones A, Sumerford D, Heckel DG, Lopez J, Micinski S, Leonardi R, Laster M (1997) Initial frequency of alleles for resistance to Bacillus thuringiensis toxins in field populations of Heliothis virescens. Proc Natl Acad Sci U S A 94:3519-3523

Grisi L, Leite RC, Martins JR, Barros AT, Andreotti R, Cançado PH, León AA, Pereira JB, Villela HS (2014) Reassessment of the potential economic impact of cattle parasites in Brazil. Rev Bras Parasitol Vet 23:150-156

Guerrero FD, Miller RJ, Pérez de León AA (2012) Cattle tick vaccines: many candidate antigens, but will a commercially viable product emerge? Int J Parasitol 42:421-427

Guerrero FD, Pérez de León A, Rodriguez-Vivas RI, Jonsson N, Miller RJ, Andreotti R (2014) Acaricide research and development, resistance and resistance monitoring. In: Biology of ticks. Sonenshine DE and Roe RReditors (2nd edition). Oxford University Press. New York. pp. 353-381

Hagen S, Koop GJA, Liebisch A (1999) Estudios de resistencia a acaricidas en la garrapara bovina Boophilus microplus en América central. In: Garcia VZ, Fragoso SH (Eds.) IV Seminario Internacional de Parasitologia Animal. Control de la resistencia en garrapatas y moscas de importancia veterinaria y enfermedades que trasmiten, CONASAG-INIFAP-INFARVET-IICA-AMPAVEFILASA, 20-22 de octubre de 1999, Puerto Vallarta, Jalisco, México, pp. 23-34

Harris RL, George JE, Ahrens EH, Davey RB, Bazan HO (1988) Selection for resistance to coumaphos in a strain of Boophilus microplus (Canestrini). J Econ Entomol 81:545-548

Hassan SM, Dipeolu OO, Malonza MM (1994) Natural attraction of livestock ticks by the leaves of a shrub. Trop Ani Hlth Prod 26: 87-91

He H, Chen AC, Davey RB, Ivie GW, George JE (1999) Identification of a point mutation in the para-type sodium channel gene from a pyrethroid-resistant cattle tick. Biochem Biophys Res Commun 261:558-561

Hernandez R, He H, Chen AC, Waghela SD, Ivie GH, George JE, Wagner G (1999) Cloning and sequencing of a putative acetylcholinesterase cDNA from Boophilus microplus (Acari: Ixodidae). J Med Entomol 36:764-770

Higa LOS, Garcia MV, Barros JC, Koller WW, Andreotti R (2016) Evaluation of Rhipicephalus (Boophilus) microplus (Acari: Ixodidae) resistance to different acaricide formulations using samples from Brazilian properties. Braz J Vet Parasitol Jaboticabal 25(2):163-171

Hillburn LR, Davey RB, George JE, Mathews PJ (1991) Non-random mating between Boophilus microplus and hybrids of B. microplus females and $B$. annulatus males, and its possible effect on sterile male hybrid control releases. Exp Appl Acarol 11:23-36

Hope M, Menzies M, Kemp D (2010) Identification of a dieldrin resistance-associated mutation in Rhipicephalus (Boophilus) microplus (Acari: Ixodidae). J Econ Entomol 103(4):1355-1359

Jobre Y, Adamu G, Zerbini E (2001) Bioassay of acaricide resistance on three common cattle tick species at Holotta, central Ethiopia. Revue Méd Vét 152(5):385-390

Jongejan F, Uilenberg G (1994) Ticks and control methods. Sci Tech Rev 13(4):1201-1226

Jonsson NN (1997) Control of cattle ticks (Boophilus microplus) on Queensland dairy farms. Aust Vet J 75(11):802-807

Jonsson NN (2004) Integrated control programs for ticks on cattle: an examination of some possible components. Food and Agriculture Organization, Rome, p 78

Jonsson NN, Hope M (2007) Progress in the epidemiology and diagnosis of amitraz resistance in the cattle tick Boophilus microplus. Vet Parasitol 146(3):193-198

Jonsson NN, Mayer DG, Green PE (2000) Possible risk factors on Queensland dairy farms for acaricide resistance in cattle tick (Boophilus microplus). Vet Parasitol 88:79-92

Jonsson NN, Miller RJ, Robertson JL (2007) Critical evaluation of the modified-adult immersion test with discriminating dose bioassay for Boophilus microplus using American and Australian isolates. Vet Parasitol 146:307-315

Jonsson NN, Cutullè C, Corley SW, Seddon JM (2010a) Identification of a mutation in the para-sodium channel gene of the cattle tick Rhipicephalus microplus associated with resistance to flumethrin but not to cypermethrin. Int J Parasitol 40:1659-1664

Jonsson NN, Miller RJ, Kemp DH, Knowles A, Ardila AE, Verrall RG, Rothwel JT (2010b) Rotation of treatments between spinosad and amitraz for the control of Rhipicephalus (Boophilus) microplus populations with amitraz resistance. Vet Parasitology 169(1-2):157-164

Jonsson NN, Piper EK, Constantinoiu CC (2014) Host resistance in cattle to infestation with the cattle tick Rhipicephalus microplus. Parasite Immunol 36(11):553-559

Jonsson NN, Klafke G, Corley SW, Tidwell J, Berry CM, Koh-Tan HHC (2018) Molecular biology of amitraz resistance in cattle ticks of the genus Rhipicephalus. Front Biosci (Landmark Ed) 23:796-810

Jyoti Singh NK, Singh H, Rath SS (2014) Malathion resistance in Rhipicephalus (Boophilus) microplus from Ludhiana district, Punjab. J Parasit Dis 38(4):343-346

Kagaruki LK (1991) Tick (Acari: Ixodidae) resistance to organochlorine acaricides in Tanzania. Trop Pest Manage 37:33-36

Kaljouw M (2009) Resistance to acaricides of Boophilus ticks from cattle in Ghana. PhD Thesis. Veterinary Medicine, Utrecht University, Netherlands

Kirkland BH, Cho EM, Keyhani ON (2004) Differential susceptibility of Amblyomma maculatum and Amblyomma americanum (Acari, Ixodidea) to the entomopathogenic fungi Beauveria bassiana and Metarhizium anisopliae. Biol Control 31:414-421

Klafke G, Webster A, Agnol BD, Pradel E, Silva J, de La Canal LH, Becker M, Osório MF, Mansson M, Barreto R, Scheffer R, Souza UA, Corassini VB, dos Santos J, Reck J, Martins JR (2016) Multiple resistance to acaricides in field populations of Rhipicephalus microplus from Rio Grande do Sul state. Southern Brazil Ticks Tick-borne Diseases 8(1):73-80 
Klafke GM, Albuquerque TA, Miller RJ, Schumaker TT (2010) Selection of an ivermectin-resistant strain of Rhipicephalus microplus (Acari: Ixodidae) in Brazil. Vet Parasitol 168(1-2):97-104

Klafke GM, Castro-Janer E, Mendes MC, Namindome A, Schumaker TT (2011) Applicability of in vitro bioassays for the diagnosis of ivermectin resistance in Rhipicephalus microplus (Acari: Ixodidae). Vet Parasitol 184(2-4):212-220

Klafke GM, Sabatini G, Albuquerque T, Martins JR, Kemp D, Miller RJ, Schumaker TT (2006) Larval immersion tests with ivermectin populations of the cattle tick Rhipicephalus (Boophilus) microplus (Acari: Ixodidae) from state of Sao Paulo, Brazil. Vet Parasitol 142(3-4):386-390

Knowles CO (1982) Structure activity relationship among amidine acaricides and insecticides. In: Coats JR (ed) Insecticide Mode of Action. Academic, New York, pp 243-277

Koh-Tan HH, Strachan E, Cooper K, Bell-Sakyi L, Jonsson NN (2016) Identification of a novel $\beta$-adrenergic octopamine receptor-like gene $(\beta A O R$-like) and increased ATP-binding cassette B10 (ABCB10) expression in a Rhipicephalus microplus cell line derived from acaricide-resistant ticks. Parasit Vectors 9(1):425

Kumar S, Paul S, Sharma AK, Kumar R, Tewari SS, Chaudhuri P, Ray DD, Rawat SS, Ghosh S (2011) Diazinon resistant status in Rhipicephalus (Boophilus) microplus collected from different agro-climatic regions of India. Vet Parasitol 181(2-4):274-281

Kunz SE, Kemp DH (1994) Insecticides and acaricides: resistance and environmental impact. Rev Sci Tech 13:1249-1286

Kwon DH, Yoon KS, Clark JM, Lee SH (2010) A point mutation in a glutamate-gated chloride channel confers abamectin resistance in the two-spotted spider mite, Tetranychus urticae Koch. Insect Mol Biol 19(4):583-591

Li AY, Chen AC, Davey RB, Miller RJ, George JE (2007) Acaricide resistance and synergism between permethrin and amitraz against susceptible and resistant strains of Boophilus microplus (Acari, Ixodidae). Pest Manag Sci 63:882-889

Li AY, Davey RB, George JE (2005) Carbaryl resistance in Mexican strains of the southern cattle tick (Acari: Ixodidae). J Econ Entomol 98(2):552-556

Li AY, Davey RB, Miller RJ (2010) Laboratory evaluation of verbutinas a synergist of acaricides against larvae of Rhipicephalus (Boophilus) microplus (Acari: Ixodidae). J Econ Entomol 103(4):1360-1364

Li AY, Davey RB, Miller RJ, George JE (2003) Resistance to coumaphos and diazinon in Boophilus microplus (Acari: Ixodidae) and evidence for the involvement of an oxidative. J Med Entomol 40(4):482-490

Li AY, Davey RB, Miller RJ, George JE (2004) Detection and characterization of amitraz resistance in the southern cattle tick, Boophilus microplus (Acari: Ixodidae). J Med Entomol 41:193-200

Lopez-Arias A, Villar-Argaiz D, Chaparro-Gutierrez JJ, Miller RJ, Perez de Leon AA (2014) Reduced efficacy of commercial acaricides against populations of resistant cattle tick Rhipicephalus microplus from two municipalities of Antioquia, Colombia. Environ Health Insights 8(Suppl 2):71-80

Lourens JHM, Tatchell RJ (1979) Studies on acaricide resistance in Rhipicephalus evertsi evertsi Neumann (Acarina: Ixodidae) in East Africa. Identification and inheritance of a resistance factor to organochlorines. Bull Entomol Res 69:235-242

Lovis L, Reggi J, Berggoetz M, Betschart B, Sager H (2013) Determination of acaricide resistance in Rhipicephalus (Boophilus) microplus (Acari: Ixodidae) field populations of Argentina, South Africa, and Australia with the larval tarsal test. J Med Entomol 50(2):326-335

Luguru SM, Chizyuka HGB, Musisi FL (1987) A survey for resistanceto acaricides in cattle ticks (Acari: Ixodidae) in three major traditional cattle areas in Zambia. Bull Entomol Res 77:569-574

Mackinnon MJ, Meyer K, Hetzel DJS (1991) Genetic variation and correlation for growth, parasite resistance and heat tolerance in tropical cattle. Livest Prod Sci 27:105-122
MacDonald JM (1995) Flea control, on overview of treatment concepts for North America. Vet Dermatol 6:121-130

Mangold AJ, Castelli ME, Nava S, Aguirre DH, Guglielmone AA (2004) Poblaciones de la garrapata Rhipicephalus (Boophilus) microplus resistentes a los piretroides en Córdoba y Salta, Argentina. Revista FAVE - Cienc Vet 3(1-2):55-59

Manjunathachar HV, Saravanan BC, Kesavan M, Karthik K, Rathod P, Gopi M, Tamilmahan P, Balaraju BL (2014) Economic importance of ticks and their effective control strategies. Asian Pac J Trop Dis 4(Suppl 2):S770-S779

Martins J, Furlong J (2001) Avermectin resistance of the cattle tick Boophilus microplus in Brazil. Vet Rec 149(2):64

Matthewson MD, Blackman GG (1980) Resistance to certain organophosphorus ixodicides in strains of Boophilus decoloratus from Zambia. Vet Record 107(21):491

Mazhowu WA (1995) Survey for resistance to acaricides in cattle ticks (Acari: Ixodidae) in Zimbabwe. Available in: http://agris.fao.org/ agris-search/search.do?recordID=MX1997002809

McKenzie JA (1996) Ecological and evolutionary aspects of insecticide resistance. R.G. Landes-Academic Press, Austin, Texas

Mekonnen S, Bryson NR, Fourie LJ, Peter RJ, Spickett AM, Taylor RJ, Strydom T, Kemp DH, Horak IG (2003) Comparison of 3 tests to detect acaricide resistance in Boophilus decoloratus on dairy farms in the Eastern Cape Province, South Africa. JJ S Afr Vet Assoc 74(2):41-44

Mekonnen S, Bryson NR, Fourie LJ, Peter RJ, Spickett AM, Taylor RJ, Strydom T, Horak IG (2002) Acaricide resistance profiles of singleand multi-host ticks from communal and commercial farming areas in the Eastern Cape and north-west provinces of South Africa. Onderstepoort J Vet Res 69(2):99-105

Mendes MC, Lima CKP, Nogueira AHC, Yoshihara E, Chiebao DP, Gabriel FHL, Uenod TEH, Namindome A, Klafke GM (2011) Resistance to cypermethrin, deltamethrin and chlorpyriphos in populations of Rhipicephalus (Boophilus) microplus (Acari: Ixodidae) from small farms of the state of São Paulo, Brazil. Vet Para 178: 383-388

Mendes MC, Pereira JR, Prado AP (2007) Sensitivity of Boophilus microplus (acari: ixodidae) to pyrethroids and organophosphate in farms in the Vale do Paraíba region, São Paulo, Brazil. Arq Inst Biol, São Paulo 74(2):81-85

Miller R, Davey RB, White WH, George JE (2007a) A comparison of three bioassay techniques to determine amitraz susceptibility in Boophilus microplus (Acari: Ixodidae). J Med Entomol 44:283-294

Miller RJ, Almazán C, Ortíz-Estrada M, Davey RB, George JE, Peréz de León A (2013) First report of fipronil resistance in Rhipicephalus (Boophilus) microplus of Mexico. Vet Parasitol 191:97-101

Miller RJ, Davey RB, George J (1999) Characterization of pyrethroid resistance and susceptibility to coumaphos in Mexican Boophilus microplus (Acari: Ixodidae). J Med Entomol 36:533-538

Miller RJ, Davey RB, George JE (2005) First report of organophosphateresistant Boophilus microplus (Acari: Ixodidae) within the United States. J Med Entomol 42(5):912-917

Miller RJ, Davey RB, George JE (2007b) First report of permethrinresistant Boophilus microplus (Acari: Ixodidae) collected within the United States. J Med Entomol 44(2):308-315

Morgan JAT, Corley SW, Jackson LA, Lew-Tabor AE, Moolhuijzen PM, Jonsson NN (2009) Identification of a mutation in the para-sodium channelgene of the cattle tick Rhipicephalus (Boophilus) microplus associated with resistance to synthetic pyrethroid acaricides. Int $\mathrm{J}$ Parasitol 39:775-779

Muhammad G, Naureen A, Firyal S, Saqib M (2008) Tick control strategies in dairy production medicine. Pak Vet J 28(1):43-50

Muyobela J, Nkunika POY, Mwase ET (2015) Resistance status of ticks (Acari: Ixodidae) to amitraz and cypermethrin acaricides in Isoka District, Zambia. Trop Anim Hlth Prod 47(8):1599-1605 
Muyobela J, Yobe-Nkunika PO, Tembo-Mwase E (2016) In vitro acaricidal activity of Bobgunnia madagascariensis Desv. against Amblyomma variegatum (Fabricius) (Acari: Ixodidae). Trop Anim Hlth Prod 48:625-631

Nagar G, Sharma AK, Chigure G, Manjunathachar HV, Saravanan BC, Rai A, Ghosh S (2016) Identification of mutations in acetylcholinesterase 2 gene of acaricide resistant isolates of Rhipicephalus (Boophilus) microplus. Int J Sci Environ Technol 5:3440-3447

Nolan J, Wilson JT, Green PE, Bird PE (1989) Synthetic pyrethroid resistance in field samples in the cattle tick (Boophilus microplus). Aust Vet J 66:179-182

Ntondini Z, van Dalen EMSP, Horak IG (2008) The extent of acaricide resistance in 1-, 2- and 3-host ticks on communally grazed cattle in the eastern region of the Eastern Cape Province, South Africa. J S Afr Vet Assoc 79(3):130-135

Ojeda-Chi MM, Rodriguez-Vivas RI, Galindo-Velasco E, LezamaGutierrez R (2010) Laboratory and field evaluation of Metarhizium anisopliae (Deuteromycotina: Hyphomycetes) for the control of Rhipicephalus microplus (Acari: Ixodidae) in the Mexican tropics. Vet Parasitol 170:348-354

Ojeda-Chi MM, Rodriguez-Vivas RI, Galindo-Velasco E, LezamaGutiérrrez R, Cruz-Vazquez C (2011) Control de Rhipicephalus microplus (Acari: ixodidae) mediante el uso del hongo entomopatógeno Metarhizium anisopliae (Hipocreales: Clavicipitaceae). Rev Mex Cien Pec 2(2):177-192

Olivares-Pérez J, Rojas-Hernández S, Valencia-Almazan MT, GutiérrezSegura I, Míreles-Martínez EJ (2011) Prevalence of resistant strains of Rhipicephalus microplus to acaricides in cattle ranch in the tropical region of Tecpan of Galeana, Guerrero, Mexico. Pak Vet J 31(4): 366-368

Oliveira EE, Guedes RNC, Tótola MR, De Marco P (2007) Competition between insecticide-susceptible and -resistant populations of the maize weevil, Sitophilus zeamais. Chemosphere 69(1):17-24

Ortiz EM, Santamaría VM, Ortiz NA, Soberanes CN, Osorio MJ, Franco BR, Martinez IF, Quezada DR, Fragoso SH (1995) Characterization of Boophilus microplus resistance to ixodicides in México. In: Seminario internacional de Parasitología Animal. Acapulco, México, pp 58-66

Osburn RL, Knipling EF (1982) The potential use of sterile hybrid Boophilus ticks (Acari: Ixodidae) as a supplemental eradication technique. J Med Entomol 19:637-644

Ozoe Y, Asahi M, Ozoe F, Nakahira K, Mita T (2010) The antiparasitic isoxazoline A1443 is a potent blocker of insect ligand-gated chloride channels. Biochem Biophys Res Commun 391:744-749

Pamo ET, Tendonkeng F, Kana JR, Payne VK, Boukila B, Lemoufouet J (2005) A study of the acaricidal properties of an essential oil extracted from the leaves of Ageratus houstonianum. Vet Parasitol 128: 319-323

Pereira MC, Labruna MB, Szabó MPJ, Klafke GM (2008) Rhipicephalus (Boophilus) microplus: biologia, controle e resistência. In: Editora Med Vet, Sao Paulo, Brasil

Perez-Cogollo LC, Rodriguez-Vivas RI, Ramirez-Cruz GT, Miller RJ (2010a) First report of the cattle tick Rhipicephalus microplus resistant to ivermectin in Mexico. Vet Parasitol 168(1-2):165-169

Perez-Cogollo LC, Rodriguez-Vivas RI, Ramirez-Cruz GT, RosadoAguilar JA (2010b) Survey of Rhipicephalus microplus resistance to ivermectin at cattle farms with history of macrocyclic lactones use in Yucatan, Mexico. Vet Parasitol 172:109-113

Pohl PC, Klafke GM, Júnior JR, Martins JR, da Silva Vaz Jr I, Masuda A (2012) ABC transporters as a multidrug detoxification mechanism in Rhipicephalus (Boophilus) microplus. Parasitol Res 111:2345-2351

Porto Neto LR, Jonsson NN, D’Occhio MJ, Barendse W (2011) Molecular genetic approaches for identifying the basis of variation in resistance to tick infestation in cattle. Vet Parasitol 180:165-172
Prullage JB, Cawthorne WG, Le Hir de Fallois LP, Timmons PR (2011) Synergy between fipronil and amitraz in a Rhipicephalus sanguineus tick residual contact test. Exp Appl Acarol 54:173-176

Puerta JM, Chaparro JJ, Lopez-Arias A, Arias Arroyave S, Villar D (2015) Loss of in vitro efficacy of topical commercial acaricides on Rhipicephalus microplus (Ixodida: Ixodidae) from Antioquian farms, Colombia. J Med Entomol 52(6):1309-1314

Rawlins SC, Mansingh A (1978) Patterns of resistance to various acaricides in some Jamaican populations of Boophilus microplus. J Econ Entomol 71:956-960

Reck J, Klafke GM, Webster A, Dall'Agnol B, Scheffer R, Araújo Souza U, Bamberg Corassini V, Vargas R, Silveira dos Santos J, de Souza Martins JR (2014) First report of fluazuron resistance in Rhipicephalus microplus: a field tick population resistant to six classes of acaricides. Vet Para 201:128-136

Redondo M, Fragoso H, Ortíz M, Montero C, Lona J, Medellín JA, Fría R, Hernández V, Franco R, Machado H, Rodríguez M, de la Fuente J (1999) Control of chemically resistant Boophilus microplus populations on grazing cattle vaccinated with Gavac ${ }^{\circledR}$ in Mexico. Exp Appl Acarol 23:841-849

Regassa A, de Castro JJ (1993) Tick resistance to acaricides in Western Ethiopia. Trop Anim Health Prod 25:69-74

Robbertse L, Baron S, van der Merwe NA, Madder M, Stoltsz WH, Maritz-Olivier C (2016) Genetic diversity, acaricide resistance status and evolutionary potential of a Rhipicephalus microplus population from a disease-controlled cattle farming area in South Africa. Ticks Tick-borne Dis 7(4):595-603

Robertson JL, Russell RM, Priesler HK, Savin NE (2007) Bioassay with artropods, second edn. CRC Press, Boca Raton

Rodriguez-Vivas RI (2008) The effect of selection pressure on the genotype and phenotype of acaricide resistance in Rhipicephalus (Boophilus) microplus. PhD Thesis University of Liverpool, pp. 189

Rodriguez-Vivas RI, Quiñones AF, Fragoso SH (2005) Epidemiología y control de la garrapata Boophilus en México. In: Rodríguez-Vivas RI. Enfermedades de importancia económica en producción animal. México: McGraw-Hill. p. 571-592

Rodriguez-Vivas RI, Alonso-Diaz MA, Rodriguez-Arevalo F, FragosoSanchez H, Santamaria VM, Rosario-Cruz R (2006a) Prevalence and potential risk factors for organophosphate and pyrethroid resistance in Boophilus microplus ticks on cattle ranches from the state of Yucatan, Mexico. Vet Parasitol 136:335-342

Rodriguez-Vivas RI, Rodriguez-Arevalo F, Alonso-Díaz MA, FragosoSanchez H, Santamaria VM, Rosario-Cruz R (2006b) Prevalence and potential risk factors for amitraz resistance in Boophilus microplus ticks in cattle farms from the state of Yucatan, Mexico. Prev Vet Med 75(3-4):280-286

Rodriguez-Vivas RI, Rivas AL, Chowell G, Fragoso SH, Rosario CR, Garcia Z, Smith SD, Williams JJ, Schwager SJ (2007) Spatial distribution of acaricide profiles (Boophilus microplus strains susceptible or resistant to acaricides) in southeastern Mexico. Vet Parasitol 146:158-169

Rodriguez-Vivas RI, Trees AJ, Rosado-Aguilar JA, Villegas-Perez SL, Hodgkinson JE (2011) Evolution of acaricide resistance: phenotypic and genotypic changes in field populations of Rhipicephalus (Boophilus) microplus in response to pyrethroid selection pressure. Int J Parasitol 41:895-903

Rodriguez-Vivas RI, Hodgkinson JE, Trees AJ (2012a) Resistencia a los acaricidas en Rhipicephalus (Boophilus) microplus: situación actual y mecanismos de resistencia. Rev Mex Cienc Pecu 3(S1):9-24

Rodriguez-Vivas RI, Hodgkinson JE, Rosado-Aguilar JA, Villegas-Perez SL, Trees AJ (2012b) The prevalence of pyrethroid resistance phenotype and genotype in Rhipicephalus (Boophilus) microplus in Yucatan, Mexico. Vet Parasitol 184(2-4):221-229

Rodriguez-Vivas RI, Li AY, Ojeda-Chi MM, Trinidad-Martinez I, Rosado-Aguilar JA, Miller RJ, Pérez de León AA (2013) In vitro and in vivo evaluation of cypermethrin, amitraz, and piperonyl 
butoxide mixture $\mathrm{s}$ for the control of resistant Rhipicephalus (Boophilus) microplus (Acari: Ixodidae) in the Mexican tropics. Vet Parasitol 197(1-2):288-296

Rodriguez-Vivas RI, Perez-Cogollo LC, Rosado-Aguilar JA, Ojeda-Chi MM, Trinidad-Martinez I, Miller RJ, Li AY, Perez de Leon AA, Guerrero FD, Klafke GM (2014a) Rhipicephalus microplus resistant to acaricides and ivermectin in cattle farms of Mexico. Braz J Vet Parasitol 23(2):113-122

Rodriguez-Vivas RI, Rosado-Aguilar JA, Ojeda-Chi MM, Pérez-Cogollo LC, Trinidad-Martínez I, Bolio-González ME (2014b) Control integrado de garrapatas en la ganadería bovina. Ecos Rec Agrop 1(3):295-308

Rodriguez-Vivas RI, Miller RJ, Ojeda-Chi MM, Rosado-Aguilar JA, Trinidad-Martínez IC, Pérez de León AA (2014c) Acaricide and ivermectin resistance in a field population of Rhipicephalus microplus (Acari: Ixodidae) collected from red deer (Cervus elaphus) in the Mexican tropics. Vet Parasitol 200(1-2):179-188

Rodriguez-Vivas RI, Grisi L, Pérez de León AA, Silva Villela H, TorresAcosta JFJ, Fragoso Sánchez H, Romero Salas D, Rosario Cruz R, Saldierna F, García-Carrasco D (2017) Potential economic impact assessment for cattle parasites in Mexico review. Rev Mex Cienc Pec 8(1):61-74

Rosado-Aguilar JA, Aguilar-Caballero A, Rodriguez-Vivas RI, BorgesArgaez R, Garcia-Vazquez Z, Mendez-Gonzalez M (2010) Acaricidal activity of extracts from Petiveria alliacea (Phytolaccaceae) against the cattle tick, Rhipicephalus (Boophilus) microplus (Acari: ixodidae). Vet Parasitol 168(3-4):299-303

Rosado-Aguilar JA, Arjona-Cambranes K, Torres-Acosta JF, RodríguezVivas RI, Bolio-González ME, Ortega-Pacheco A, Alzina-López A, Gutiérrez-Ruiz EJ, Gutiérrez-Blanco E, Aguilar-Caballero AJ (2017) Plant products and secondary metabolites with acaricide activity against ticks. Vet Parasitol 138:66-76

Rosado-Aguilar JA, Rodriguez-Vivas RI, Garcia-Vazquez Z, FragosoSanchez H, Ortiz-Najera A, Rosario-Cruz R (2008) Development of amitraz resistance in field populations of Boophilus microplus (Acari: Ixodidae) undergoing typical amitraz exposure in the Mexican tropics. Vet Parasitol 152:349-353

Rosario-Cruz R, Guerrero FD, Miller RJ, Rodriguez-Vivas RI, Dominguez-Garcia DI, Cornel AJ, Hernández-Ortiz R, George EJ (2005) Roles played by esterase activity and by a sodium channel mutation involved in pyrethroid resistance in populations of Boophilus microplus (Canestrini) (Acari: Ixodidae) collected from Yucatan, Mexico. J Med Entomol 42(6):1020-1025

Rosario-Cruz R, Guerrero FD, Miller RJ, Rodriguez-Vivas RI, Tijerina M, Dominguez-Garcia DI, Hernandez-Ortiz R, Cornel AJ, McAbee RD, Alonso-Diaz MA (2009) Molecular survey of pyrethroid resistance mechanisms in Mexican field populations of Rhipicephalus (Boophilus) microplus. Parasitol Res 105:1145-1153

Roulston WJ, Whartons RH, Nolan J, Kerr JD, Wilson JT, Thompson PG, Scho M (1981) A survey for resistance in cattle ticks to acarlcldes. Aust Ve J 57:362-371

Roush RT, McKenzie JA (1987) Ecological genetics of insecticide and acaricide resistance. Annu Rev Entomol 32:361

Samish M, Ginsberg H, Glazer I (2004) Biological control of ticks. Parasitology 129:S389-S403

Sardá-Ribeiro VL, Rolim V, Bordignon S, Henriques AT, Dorneles GG, Limberger RP, von Poser G (2008) Chemical composition and larvicidal properties of the essential oils from Drimys brasiliensis Miers (Winteraceae) on the cattle tick Rhipicephalus (Boophilus) microplus and the brown dog tick Rhipicephalus sanguineus. Parasitol Res 102:531-535

Schetters T, Bishop R, Crampton M, Kopáček P, Lew-Tabor A, MaritzOlivier C, Miller R, Mosqueda M, Patarroyo J, Rodriguez-Valle M, Scoles GA, de la Fuente J (2016) Cattle tick vaccine researchers join forces in CATVAC. Parasites Vectors 9:105
Sharma AK, Kumar R, Kumar S, Nagar G, Singh NK, Rawat SS, Dhakad ML, Rawat AK, Ray DD, Ghosh S (2012) Deltamethrin and cypermethrin resistance status of Rhipicephalus (Boophilus) microplus collected from six agro-climatic regions of India. Vet Parasitol 188(3-4):337-345

Shaw RD (1966) Culture of an organophosphorus-resistant strain of Boophilus microplus (Can.) and an assessment of its resistance spectrum. Bull Ent Res 56:389-405

Shyma KP, Gupta JP, Singh V, Patel KK (2015) In vitro detection of acaricidal resistance status of Rhipicephalus (Boophilus) microplus against commercial preparation of deltamethrin, flumethrin, and fipronil from North Gujarat. India J Parasitol Res Article ID 506586:7

Shyma KP, Kumar S, Sangwan AK, Sharma AK, Nagar G, Ray DD, Ghosh S (2013) Acaricide resistance status of Rhipicephalus (Boophilus) microplus and Hyalomma anatolicum collected from Haryana. Indian J Anim Sci 83(6):591-594

Sibson GJ (1994) The effects of moxidectin against natural infestation of cattle tick Boophilus microplus. Aust Vet J 71:22-23

SINDAN (2013) (Sindicato Nacional da Indústria de Produtos para Saúde Animal). São Paulo, SP, Brazil. Available from: http://www.sindan. org.br

Sindhu ZD, Jonsson NN, Iqbal Z (2012) Syringe test (modified larval immersion test): a new bioassay for testing acaricidal activity of plant extracts against Rhipicephalus microplus. Vet Parasitol 188: 362-367

Singh NK, Gelot IS, Jyoti SV, Rath SS (2015) Detection of amitraz resistance in Rhipicephalus (Boophilus) microplus from North Gujarat. India J Parasit Dis 39:49-52

Singh NK, Jyoti HM, Singh H, Rath SS, Ghosh S (2014) A comparative study on cypermethrin resistance in Rhipicephalus (Boophilus) microplus and Hyalomma anatolicum from Punjab (India). Ticks and Tick-borne Dis 5(2):90-94

Singh NK, Singh H, Singh NK, Rath SS (2016) Multiple mutations in the acetylcholinesterase 3 gene associated with organophosphate resistance in Rhipicephalus (Boophilus) microplus ticks from Punjab, India. Vet Parasitol 216:108-117

Soberanes CN, Santamaría VM, Fragoso SH, García VZ (2002) Primer caso de resistencia al amitraz en la garrapata del ganado Boophilus microplus en México. Téc Pec Méx 40:81-90

Soderlund DM, Clark JM, Sheets LP, Mullin LS, Piccirillo VJ, Sargent D, Stevens JT, Weiner ML (2002) Mechanisms of pyrethroid neurotoxicity, implications for cumulative risk assessment. Toxicol 171:359.

Srivastava R, Ghosh S, Mandal DB, Azhahianambi P, Singhal PS, Pandey NN, Swarup D (2008) Efficacy of Azadirachta indica extracts against Boophilus microplus. Parasitol Res 104(1):149-153

Stachurski F, Adakal H (2010) Exploiting the heterogeneous dropoffrhythm of Amblyomma variegatum nymphs to reduce pasture infestation by adult ticks. Parasitology 137:1129-1137

Stone BF, Haydock P (1962) A method for measuring the acaricides susceptibility of the cattle tick Boophilus microplus (Can.) Bull Entomol Res 53:563-578

Stone BF, Meyers RAJ (1957) Dieldrin-resistant cattle ticks, Boophilus microplus (Canestrini) in Queensland. Aust J Agricul Res 8(3):312-317

Stone BF, Webber LG (1960) Cattle ticks, Boophilus microplus, resistant to DDT, BHC, and Dieldrin. Aust J Agric Res 11(1):106-119

Stone NE, Olafson PO, Davey RB, Buckmeier G, Bodine D, Sidak-Loftis LC, Giles JR, Duhaime R, Miller RJ, Mosqueda J, Scoles GA, Wagner DM, Busch JD (2014) Multiple mutations in the parasodium channel gene are associated with pyrethroid resistance in Rhipicephalus microplus from the United States and Mexico. Parasites Vectors 7:456 
Sutherst RW (1979) Management of acaricide resistance in cattle tick Boophilus microplus (Acari Ixodidae) in Australia. Bull Entomol Res 69:519-537

Sutherst RW, Kerr JD, Maywald GF, Stegeman DA (1983) The effectof season and nutrition on the resistance of cattle to the tick Boophilusmicroplus. Aust J Agric Res 34:329-339

Tapia-Perez G, García-Vázquez Z, Montaldo H, George JE (2003) Inheritance of resistance to flumethrin in the Mexican Aldama strain of cattle tick Boophilus microplus (Acari: Ixodidae). Exp Appl Acarol 31:135-149

Taylor MA (2001) Recent developments in ectoparasiticides. Vet J 161(3):253-268

Temeyer KB, Davey RB, Chen AC (2004) Identification of a third Boophilus microplus (Acari: Ixodidae) cDNA presumptively encoding an acetylcholinesterase. J Med Entomol 41:259-268

Temeyer KB, Pruett JH, Olafson PU (2010) Baculovirus expression, biochemical characterization and organophosphate sensitivity of rBmAChE1, rBmAChE2, and rBmAChE3 of Rhipicephalus (Boophilus) microplus. Vet Parasitol 172:114-121

Temeyer KB, Pruett JH, Olafson PU, Chen AC (2007) R86Q, a mutation in BmAChE3 yielding a Rhipicephalus microplus organophosphateinsensitive acetylcholinesterase. J Med Entomol 44(6):1013-1018

Thullner F, Willadsen P, Kemp D (2007) Acaricide rotation strategy for managing resistance in the tick Rhipicephalus (Boophilus) microplus (Acarina: Ixodidae): laboratory experiment with a field strain from Costa Rica. J Med Entomol 44(5):817-821

Torrijos MJ, Avarez-Calderón V, Quintero-Noriega R, Espinales K, Rangel-Tapia G, Quintero-Vega N (2015) Sensibilidad al clorpirifos y cipermetrina en la garrapata Rhipicephalus microplus en fincas ganaderas de panamá. Cien Agropec 2:70-77

Usmani KA, Knowles CO (2001) Toxicity of pyrethroids and effect of synergists to larval and adult Helicoverpa zea, Spodoptera frugiperda, and Agrotis ipsilon (Lepidoptera: Noctuidae). J Econ Entomol 94:868-873

Utech KBW, Wharton RH, Kerr JD (1978) Resistance to Boophilus microplus (Canestrini) to different breeds of cattle. Aust JAgric Res 29:885-895

Valdez RM, Mendez ML, Guerra AA, Barrios HP, Rodriguez SI, Leyva RA (1999) In: Garcia VZ, Fragoso SH (Eds.) IV Seminario Internacional de Parasitologia Animal. Control de la resistencia en garrapatas y moscas de importancia veterinaria y enfermedades que trasmiten, CONASAG-INIFAP-INFARVET-IICA-AMPAVEFILASA, 20-22 de octubre de 1999, Puerto Vallarta, Jalisco, México, pp. 57-63

van Wyk RDJ, Baron S, Maritz-Olivier C (2016) An integrative approach to understanding pyrethroid resistance in Rhipicephalus microplus and $R$. decoloratus ticks. Ticks and Tick-borne Diseases 7:586-594

Veiga LPHN, Pereira de Souza A, Bellato SAA, de Oliveira Nunes AP, Mondardo Cardoso H (2012) Resistance to cypermethrin and amitraz in Rhipicephalus (Boophilus) microplus on the Santa Catarina Plateau, Brazil. Rev Bras Parasitol Vet 21(2):133-136

Villar D, Gutiérrez J, Piedrahita D, Rodríguez-Durán A, Cortés-Vecino JA, Góngora-Orjuela A, Martínez N, Chaparro-Gutiérrez JJ (2016b) Resistencia in vitro a acaricidas tópicos de poblaciones de garrapatas Rhipicephalus (Boophilus) microplus provenientes de cuatro departamentos de Colombia. Rev CES Med Zootec 11(3):58-70

Villar D, Puerta J, Lopez A, Chaparro JJ (2016a) Ivermectin resistance of three Rhipicephalus microplus populations using the larval immersion test. Rev Colom Cienc Pecua 29(19):51-57

Villarroel-Alvarez M, Rodríguez-Vivas RI, Villegas-Anze F, FragosoSánchez H, Ortiz-Nájera A, Neri-Orantes S (2006) Prevalencia de lecherías con Boophilus microplus resistentes a piretroides y factores de riesgo asociados a su presencia en el Departamento de Santa Cruz, Bolivia. Téc Pec Méx 44(2):155-167

Vudriko P, Okwee-Acai J, Tayebwa DS, Byaruhanga J, Kakooza S, Wampande E, Suzuki H (2016) Emergence of multi-acaricide resistant Rhipicephalus ticks and its implication on chemical tick control in Uganda. Parasites Vectors 9:4

Webster A, Reck J, Santi L, Souza UA, Dall'Agnol B, Klafke GM, Beysda-Silva WO, Martins JR, Schrank A (2015) Integrated control of an acaricide-resistant strain of the cattle tick Rhipicephalus microplus by applying Metarhizium anisopliae associated with cypermethrin and chlorpyriphos under field conditions. Vet Parasitol 207(3-4): 302-308

White WH, Plummer PR, Kemper CJ, Miller RJ, Davey RB, Kemp DH, Hughes S, Smith CK II, Gutierrez JA (2004) An in vitro larval immersion microassay for identifying and characterizing candidate acaricides. J Med Entomol 41:1034-1042

Wikel S (2013) Ticks and tick-borne pathogens at the cutaneous interface: host defenses, tick countermeasures, and a suitable environment for pathogen establishment. Front Microbial 4:337

Wikel SK (1996) Host immunity to ticks. Annu Rev Entomol 41:1-22

Willadsen P (2006) Tick control, thoughts on a research agenda. Vet Parasitol 138:161-168

Willadsen P, Bird P, Cobon GS, Hungerford J (1995) Comercialization of a recombinant vaccine against Boophilus microplus. Parasitology 110:S43-S50

Willadsen P, Reding GA, McKenna RV, Kemp DH, Tellam RL, Nielsen JN, Lahnstein J, Cobon GS, Gough JM (1989) Immunological control of a parasitic arthropod identification of a protective antigen from Boophilus microplus. J Immunol 143:1346-1351

Wilson LJ, Sutherst RW, Kerr JD (1989) Trapping of the cattle tick Boophilus microplus by Stylosanthes scabra under grazing conditions. Aust J Agric Res 40:1301-1308

WingChing-Jones R (2015) Extracción manual de garrapatas Riphicephalus (Boophilus) microplus en ganado bovino como estrategia de control. Nutr Anim Trop 9(1):88-101

Wondji C, Dabire RK, Zainab T, Helen I, Rousseau D, Morgan J (2011) Identification and distribution of a GABA receptor mutation conferring dieldrin resistance in the malaria vector Anopheles funestus in Africa. Insect Biochem Molec Biol 41(7):484-491

Wright FC, Ahrens EH (1989) Metabolism of in coumaphos in susceptible and resistant strains of Boophilus microplus (Acari: Ixodidae). J Med Entomol 25(2):94-98

Yilma J, Adamu G, Zerbini E (2001) Biossay of acaricide resistance on three common cattle tick species at Holotta, Central Ethiopia. Revue Méd Vét 152(5):385-390

Young S, Gunning RV, Moores GD (2006) The effect of pretreatmentwith piperonyl butoxide on pyrethroid efficacy against insecticide-resistant Helicoverpa armigera (Lepidoptera, Noctuidae) and Bemisia tabaci (Sternorrhyncha: Aleyrodidae). Pest Manag Sci 62:114-119

Ziapour SP, Kheiri S, Asgarian F, Fazeli-Dinan M, Yazdi F, Mohammadpour RL, Aarab M, Enayati A (2016a) First report of pyrethroid resistance in Rhipicephalus (Boophilus) annulatus larvae (Say, 1821) from Iran. Acta Trop 156:22-29

Ziapour SP, Kheiri S, Fazeli-Dinan M, Sahraei-Rostami F, Mohammadpour RA, Aarabi M, Asgarian F, Sarafrazi M, Nikookar SH, Enayati A (2016b) Susceptibility status of field populations of Rhipicephalus bursa (Acari: Ixodidae) to pyrethroid insecticides. Trop Biomed 33(3):446-461 